\title{
Strategy of Habitat Utilization by European bison in the Białowieża Forest
}

\author{
Małgorzata KRASIŃSKA, Krystyna CABON-RACZYNSSKA \\ \& Zbigniew A. KRASINSKI
}

Krasińska M. Caboń-Raczyńska K. \& Krasiński Z. A., 1987: Strategy of habitat utilization by European bison in the Bialowieża Forest. Acta theriol., 32, 11: 147-202 [With 8 Tables \& 18 Figs.]

The strategy of habitat utilization in the Bialowieża Primeval Forest was analysed for mixed groups of bison, which included marked individuals, in the period without snow cover over 1977-1982. In addition to the groups of bulls, which are not analysed in this paper, the basic structural unit is a mixed group. The optimal group size in a forest habitat is about 20 individuals. The size and composition of mixed groups are variable. The longest periods of group stability were recorded in April and May, and the shortest in July. Changes in groups result from behavioral factors (rut, calving) and other factors such as sharing an area, encounters of groups, and exchange of individuals. The mothercalf relationships are terminated at an age of $2-3$ years. Adult cows are most stable elements of the group, whereas young bulls are the most variable elements of it. The spatial structure of mixed groups in periods without snow cover is influenced by relationshjps developed in two large winter aggregations. Groups formed from different aggregations occupy separate, relatively stable ranges. Single group occupies an area $4700 \pm 720.2$ ha from April to October. The range of a group varies over the season, and individual groups do not show territorial behavior. Mean monthly range size of a group is $2100 \pm 885.7$ ha. It is small in April and the largest in May, stable in July, and decreasing until autumn before winter aggregations are formed. The main factor determining movements through the forest is searching for preferred foraging areas. In May, bison covered the longest distances - up to $11,750 \mathrm{~m}$ during 24 hours, but the mean distance over the season was $2034 \pm 1475.8 \mathrm{~m}$. The shortest distance was noted in July $(140 \mathrm{~m})$. The main habitats of bison consist of fresh and moist deciduous forests and mixed coniferous forests ( $80 \%$ of observations). The utilization of biotopes varied with the season. In spring, deciduous forests were preferred, in summer, mixed coniferous forests and again deciduous forests in autumn, together with mixed deciduous forests. Among age classes of the forest, bison prefer treestands more then 20 years old $(72 \%$ of observations), then clearcuts, meadows and forest plantations up to ten years old $(23 \%)$. They move to the patches where the vegetation of the herb layer is at the peak of growth, and they return to the same place after several or a dozen or so days. Thus they do not overgraze the vegetation, and the herb layer can regenerate.

[Mammals Res. Inst., Polish Academy of Sciences, 17-230 Bialowieza (M. K. K. C.-R.) and Białowieża National Park, 17-230 Blałowleza (Z. A. K.), Poland]

Niniejsza praca byla wykonana w ramach problemu MR II 19 koordynowanegu przez SGGW-AR w Warszawie. 


\section{INTRODUCTION}

The European bison population in the Bialowieża Forest is a result of a successful introduction of animals bred in enclosure, from which the first individuals were released in 1952. The early period of the development of the Bialowieża herd is described in detail by Krasiniski $(1967,1983)$. After 20 years of the life in the wild, this population reached the age structure and sex ratio similar to natural, and it consisted of more than 200 individuals (Krasinski, 1978). Since 1971, the size of the herd is controlled by removing about $10 \%$ of the bison from different age classes of the two sexes each year. These eliminations stabilize the population size at a level of about 210-250 individuals (beyond the calving season), without disturbing significantly the sex ratio and age structure.

Free-living bison colonizing the Białowieża Forest showed a high degree of habitat preference (Krasinski, 1978), and they used different forest types in accordance with their species-specific requirements. In the annual activity cycle of bison, two different periods can be distinguished:

1. Period of winter aggregation, lasting from the establishment of snow cover, throughout winter, until snow melting (from mid-November to mid-April). In this period, the animals use hay for 163 days on the average (Krasiński, 1978). Hay is supplied in ricks at ten points (Fig. 1). During this time, two big winter aggregations are formed, one comprising about 60 individuals, and the other about 100 individuals, mostly calves, cows, and young animals, and few adult bulls. They stay at two feeding sites located about $4 \mathrm{~km}$ apart (forest compartments 391 and 422 , Fig. 1). The other feeding sites (Fig. 1) are utilized mostly by bulls in different ages, forming 5-8 aggregations made up of several to a dozen or so individuals, each. In addition, small mixed groups can be encountered at those feeding sites, but rarely and only at the beginning of winter. The provision of additional food in winter practically eliminates the critical period for the population and has some effect on its structure, especially on the spatial structure. It also largely reduces the utilization of natural food supply by bison in winter.

2. Period without snow cover, lasting from early spring to late autumn, that is, generally covering the growing season. In this period bison form structured herds and depend on natural food resources of the forest. When the snow cover disappeared, winter aggregations of bison split into smaller groups of two types: mixed groups and bull groups. The mixed groups consist of adult cows, calves, young of the two sexes, and, in scme periods, adult bulls. In $90 \%$ of these groups, the number of individuals is up to 20 . The groups of bulls, most frequently comprising young individuals $4-6$ years old, consist of two individuals, on the av- 


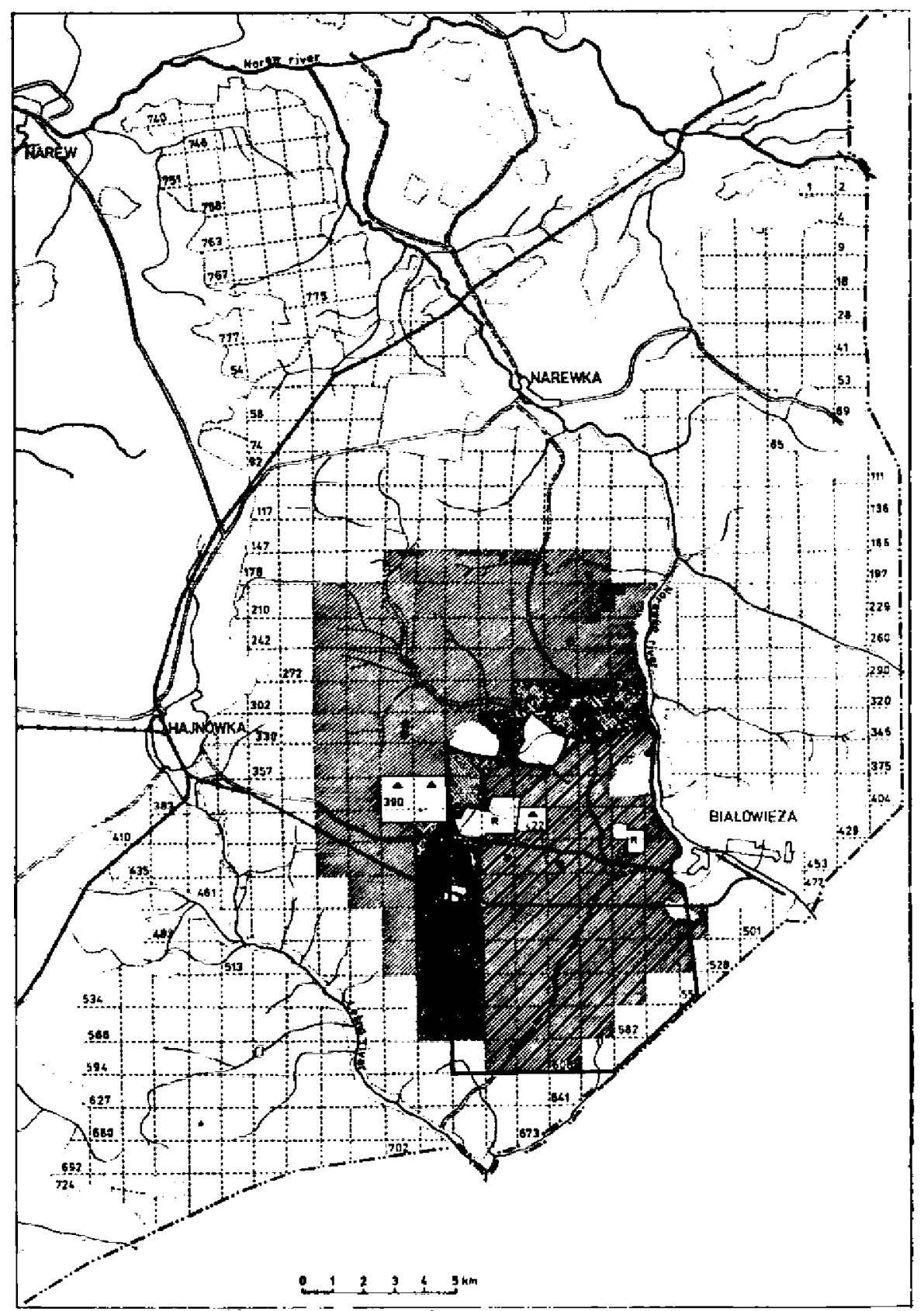

F:g. 1. Ranges of mixed groups of bison from two winter aggregations in western part of the Bialowieźa Forest. The study area is delimited by the thick line. T:iangles denote the sites of supplying additional food for bison in winter in fcrest compartments 390,391 and 422 . Closed circles denote site of supplying additional food for bulls. Note some overlapping of ranges of the two winter aggregations. 
erage. Adult bulls occurred singly in this period in about $50 \%$ of observations (Krasinski, 1978). Thus, only during the growing season the conditions in the forest enhance the restoration of natural features of the gregarious behavior of bison.

The earlier studies on the bison population in the Białowieża Forest concerned the structure and dynamics of the population (Krasinski, 1978), reproduction (Krasiński \& Raczyński, 1967), and behavior in winter aggregations (Cabon-Raczyniska et al., 1983).

Since 1976 , a new stage of the study of bison has been realized, based on direct observations of groups and marked individuals. These observations are focused on the sizes of ranges occupied by mixed groups, the way of utilizing different biotopes, changes in the size and composition of groups, habitat preferences, and utilization of food resources in the forest. The present paper analyses the results of this study.

\section{MATERIAL AND METHODS}

The study was carried out in western part of the Bialowieża Primeval Forest, on an area of about 7 thousand hectares (Fig. 1), mostly belonging to the Forest Inspectorate Bialowieza, and in part $(909$ ha) to the Forest Inspectorate Hajnowka. The study area comprised following forest types: mixed coniferous forest (MCF) $38 \%$, mixed deciduous forest (MDF) - $9.9 \%$, fresh deciduous forest (FDF) $16 \%$, moist deciduous forest (MoDF) $-13 \%$, ash-alderwood (Aa) $-10.2 \%$, alderwood (A) - 4.9\%, moist mixed coniferous forest (MoMCF) $-0.1 \%$, boggy coniferous forest (BCF) $-0.3 \%$, meadows $-0.5 \%$, and special areas enriching food supply for animals - $0.8 \%$. Deciduous forests are formed by the oak (Quercus robur), the linden (Tilia cordata), the maple (Acer platanoides) and the hornbeam (Carpinus betulus). Coniferous forests are dominated by the spruce (Picea abies) and the pine (Pinus silvestris).

The study was carried out in the period without snow cover, since the time when bison stopped using winter feeding sites early in April until they returned to these sites at the end of October. Observations focused on the bison originating from one winter aggregation (in forest compartment 422), averaging 60 (55-65 individuals), of which 25 individuals were either marked, or individually recognized by their characteristic features. Direct observations of mixed groups were conducted daily early in the morning and occasionally in the evening. Each encounter of a group or a single animal was a unit "observation". The number of animals and the composition of groups were noted, and the form of activity was recorded (foraging, resting, moving without foraging). Each encounter was located (forest compartment), the age-class of the tree stand was determined (plantation, thicket, stand more than 20 years old) along with the forest type, and the route followed by bison was described. The presence of an observer usually did not disturb the behavior and activity of bison (except for the first moment of the encounter). AIl pieces of information were stored on observation cards. The routes were mapped on a grid with a square side of $1066 \mathrm{~m}$ (a verst), to the nearest one-fourth of the forest compartment. In the cases when it was not possible to 
follow a group for successive days, its route was drawn from the tracks. The range of the group was determined each month from monthly routes.

Over 5 years, 1181 observations of mixed groups were made. The sizes of their home ranges, the rate of forest searching, and the changes in the composition and size of the group were examined. The group was identified by the permanent presence of the same marked individual. The group "Babula" was observed for five years, group No. 10 for three successive years, group "Pocieszna" for two years, whereas four other groups were observed for only one season. In each year, two groups were observed concurrently, and in 1980 three groups. To analyse the habitat preference in bisons, all field observations from 1977-1982 were used $(n=2052)$. In $1980-1982$, a detailed analysis of habitat preference was made in the following age classes of the stand: clearcuts and plantations up to ten years old, thickets up to 20 years old, and forest more than 20 years old. The total number of such observations was 1209 .

Relationships among group members were examined from the co-occurrence of marked individuals in groups coming from the common winter aggregation. This is represented in the form of diagrams (see Section 3.2.). At least 30 observations of co-occurrence per year were considered as a threshold value for a strong association among individual animals. The climatic data used in this paper come from the meteorological station located in the Bialowieża Forest, in central part of Bialowieża Glade.

\section{CHANGES IN THE NUMBER OF INDIVIDUALS AND COMPOSITION OF MIXED GROUPS, AND ASSOCIATION AMONG BISON}

\subsection{Composition and Size of the Mixed Groups}

The composition and size of mixed groups varied over the period without snow cover (Fig. 2, Tab. 1). The structure of the group was stable after its formation in early spring (April-May). This stability was ended at the onset of calving, that is, usually in mid-May. At that time, adult bulls rarely occurred in mixed groups (see Figs. 2.1 and 2.2.). Encounter and fusion of different groups were also rare $(6 \%$ of all the observations). During the calving period, which usually extends from mid-May to the end of June, frequent changes and rearrangements occurred in the composition of groups (Fig. 2). At that time, frequent encounters of groups were noted (39\% of fusions observed). Newborn calves appeared. At the same time, the proportion of cows varied because of their behavior during calving (some cows left the herd for calving, other cows joined the herd with their calves). Changes concerned also the number of individuals of other categories, which resulted in sudden changes in the group size.

In July, when the number of calvings dropped, there was a short but distinct period of relative stability of groups prior to the rutting season each year. First bulls joined the groups, which could take part in repro- 
Table 1

Composition of mixed groups of bison in 1977-1980.

$(\vec{x}$ - mean value, SD - standard deviation, CV - coefficient of variation, $O, R,-$ observed range)

\begin{tabular}{|c|c|c|c|c|c|c|c|c|}
\hline $\begin{array}{l}\text { Name or } \\
\text { number } \\
\text { of group }\end{array}$ & Year & $\mathrm{N}^{1}$ & & Calves & $\begin{array}{l}\text { Young } \\
2-3 \text { yrs }\end{array}$ & $\begin{array}{l}\text { Cows } \\
\geqslant 4 \text { yrs }\end{array}$ & $\begin{array}{l}\text { Bulls } \\
\geqslant 4 \text { yrs }\end{array}$ & $\begin{array}{l}\text { Size of } \\
\text { mixed } \\
\text { groups? }\end{array}$ \\
\hline Babula & 1977 & 61 & $\begin{array}{r}\bar{x} \\
S D \\
C V \\
\text { O.R. }\end{array}$ & $\begin{array}{r}2.2 \\
1.7 \\
129.4 \\
0-7\end{array}$ & $\begin{array}{r}4.2 \\
3.4 \\
80.9 \\
1-19\end{array}$ & $\begin{array}{r}5.5 \\
3.2 \\
58.2 \\
1-15\end{array}$ & $\begin{array}{r}1.5 \\
1.2 \\
80.0 \\
0-5\end{array}$ & $\begin{array}{r}13.4 \\
6.6 \\
49.2 \\
3 \quad 44\end{array}$ \\
\hline Babula & 1978 & 73 & $\begin{array}{r}\bar{x} \\
\mathrm{SD} \\
\mathrm{CV} \\
\mathrm{O}, \mathrm{R}\end{array}$ & $\begin{array}{r}0.8 \\
0.8 \\
100.0 \\
0-3\end{array}$ & $\begin{array}{r}8.2 \\
4.2 \\
51.8 \\
1-18\end{array}$ & $\begin{array}{r}5.2 \\
2.1 \\
40.4 \\
2-10\end{array}$ & $\begin{array}{r}0.9 \\
1.0 \\
111.1 \\
0 \quad 4\end{array}$ & $\begin{array}{r}15.1 \\
6.0 \\
39.7 \\
3-25\end{array}$ \\
\hline Babula & 1979 & 81 & $\begin{array}{r}\bar{x} \\
S D \\
C V \\
\text { O.R. }\end{array}$ & $\begin{array}{r}2.2 \\
2.0 \\
90.1 \\
0-7\end{array}$ & $\begin{array}{r}5.6 \\
3.7 \\
67.3 \\
1-17\end{array}$ & $\begin{array}{r}4.9 \\
2.3 \\
46.9 \\
2-12\end{array}$ & $\begin{array}{r}1.5 \\
1.1 \\
78.6 \\
0-6\end{array}$ & $\begin{array}{r}14.2 \\
7.1 \\
50.1 \\
.1-30\end{array}$ \\
\hline No. 10 & 1979 & 99 & $\begin{array}{r}\bar{x} \\
\text { SD } \\
\text { CV } \\
\text { O.R. }\end{array}$ & $\begin{array}{r}2.0 \\
2.0 \\
99.5 \\
0-21\end{array}$ & $\begin{array}{r}10.6 \\
4.4 \\
41.5 \\
2-18\end{array}$ & $\begin{array}{r}4.9 \\
2.2 \\
+4.9 \\
2-13\end{array}$ & $\begin{array}{r}1.2 \\
1.1 \\
91.7 \\
0-3\end{array}$ & $\begin{array}{r}18.7 \\
4.4 \\
23.5 \\
+-31\end{array}$ \\
\hline No. 10 & 1980 & 51 & $\begin{array}{r}\bar{x} \\
S D \\
C V \\
\text { O.R. }\end{array}$ & $\begin{array}{r}3.1 \\
1.9 \\
61.3 \\
0 .-6\end{array}$ & $\begin{array}{r}6.0 \\
3.8 \\
63.3 \\
2-12\end{array}$ & $\begin{array}{r}7.9 \\
2.5 \\
31.6 \\
2-17\end{array}$ & $\begin{array}{r}1.4 \\
1.3 \\
92.8 \\
0-5\end{array}$ & $\begin{array}{r}18.4 \\
7.2 \\
39.1 \\
4--31\end{array}$ \\
\hline Pocieszna & 1978 & 55 & $\begin{array}{r}\bar{x} \\
\mathrm{SD} \\
\mathrm{CV} \\
\mathrm{O} . \mathrm{R}\end{array}$ & $\begin{array}{r}0.5 \\
0.9 \\
180.0 \\
0-2\end{array}$ & $\begin{array}{r}10.8 \\
5.4 \\
50.0 \\
4-22\end{array}$ & $\begin{array}{r}6.5 \\
3.0 \\
+6.9 \\
2-10\end{array}$ & $\begin{array}{r}0.6 \\
1.1 \\
183.3 \\
0-4\end{array}$ & $\begin{array}{r}18.4 \\
8.3 \\
45.1 \\
7-32\end{array}$ \\
\hline No. 2 & 1980 & 87 & $\begin{array}{r}\overline{\boldsymbol{x}} \\
\mathrm{SD} \\
\mathrm{CV} \\
\text { O.R. }\end{array}$ & $\begin{array}{r}0.9 \\
1.2 \\
133.3 \\
0-3\end{array}$ & $\begin{array}{r}7.3 \\
3.0 \\
41.7 \\
2-16\end{array}$ & $\begin{array}{r}5.3 \\
2.4 \\
46.1 \\
4-17\end{array}$ & $\begin{array}{r}0.4 \\
0.7 \\
175.0 \\
0--3\end{array}$ & $\begin{array}{r}13.9 \\
5.2 \\
37.4 \\
9-\quad 31\end{array}$ \\
\hline No. 17 & 1980 & 110 & $\begin{array}{r}\bar{x} \\
\mathrm{SD} \\
\mathrm{CV} \\
\text { O.R. }\end{array}$ & $\begin{array}{r}2.6 \\
2.1 \\
80.8 \\
0-6\end{array}$ & $\begin{array}{r}5.6 \\
2.9 \\
51.8 \\
1-12\end{array}$ & $\begin{array}{r}7.6 \\
2.7 \\
35.5 \\
3--17\end{array}$ & $\begin{array}{r}1.6 \\
1.6 \\
106.7 \\
0-4\end{array}$ & $\begin{array}{r}17.4 \\
7.5 \\
43.1 \\
6 \quad 30\end{array}$ \\
\hline
\end{tabular}

Explanations: 1 - number of observations of a group per year; 2 only for the groups with known structure (to calculate the mean group size cited in the text (17.4) all data were used and not only those tabulated).

duction. Encounters and fusions of groups occurred less frequently than in the calving period (11\% of fusions observed).

The rutting season (August-September) was characterized by a large variability in the size and composition of groups. The number of bulls, which were very mobile at that time, was variable. Also the fusion of groups was intensified (36\% of observations of the fusions) as a result of their concentration in specific habitats (see Section 6).

The period of autumn stability coincided with the termination of the rut, usually at the end of September and in October (Figs. 2.6-2.8). 
Like i.l spring, fusions of groups were rare (8\% of the fusions). This period was terminated when the bison approached feeding sites and large winter aggregations were being formed.

If we compare the average structure of a group over the season without snow cover (Table 1), we will see a large variability. The group "Babula", which was followed for three successive years, differed in its composition. The proportion of calves in this group was significantly higher in 1977 than in $1978(p<0.001)$, whereas no difference occurred between the two following years. The proportion of the young showed a significant differences in three years (1977 and 1978: $p<0.001,1977$ and 1979: $0.05<p<0.02$; Student $t$-test). The proportion of bulls was significantly higher in 1978 than in the two other years $(0.01<p<0.005)$. Only the number of cows was similar in this group for three years (Table 1).

In group No. 10, which was observed for two years, the proportion of calves differed significantly $(0.005<p<0.002)$, and even more so for the young and cows $(p<0.001)$. But the proportion of bulls in this group was similar in the two years.

The differences between groups in the same season were significant also. In 1978, groups "Pocieszna" and "Babula" were observed, and differences occurred in the proportion of calves $(0.05<p<0.02)$, and the young and cows $(0.005<p<0.002)$, only the proportion of bulls being similar in these two groups. In 1979, a highly significant difference $(p<0.001)$ was observed between groups No. 10 and "Babula" in the proportion of the young, whereas the proportions of the other components were similar. In 1980, three groups were observed (No. 10, 2, and 17), and no differences were found in the composition of groups No. 10 and 17 , whereas in group No. 2 the proportions of calves, cows, and bulls were much lower $(p<0.001)$, and the proportion of the young was much higher than in the other groups $(0.05<p<0.02$ in comparison with group No. 10, and $0.01<p<0.005$ in comparison with group No. 17) (Table 1).

A comparison of the structure of eight groups for several years revealed the highest variation in the proportion of calves $(C V=61.3-180.0)$ and bulls $(C V=80-183.3)$, then the young $(C V=41.5-80.9)$. The proportion of cows also largely varied but within a smaller range (CV= $=35.5-58.2$ ).

Changes in the composition of groups were coupled with changes in the group size. The latter are expressed as the time of duration of a group in unchanged composition (Table 2). The longest duration of a mixed group was observed in early spring, over the period April-May, when the mean time of group duration was 16.7 (3-32) days, and it 

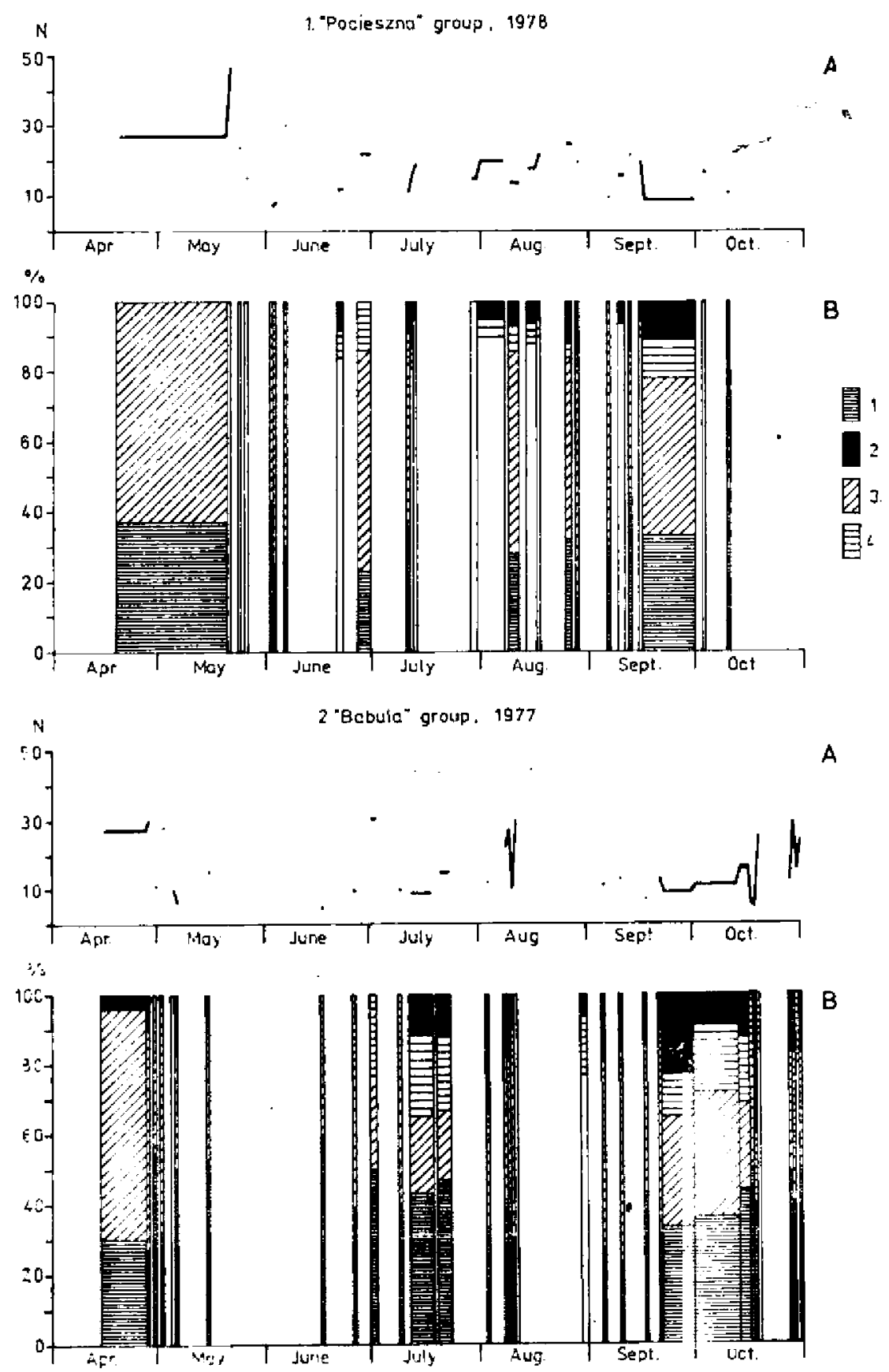

Fig. 2. Number of individuals (A) and composition (B) of mixed groups of bison. Group composition is expressed as percentage of the following categories of sex and age: (1) cows more than 4 years old, (2) bulls more than 4 years old, (3) young bisons $2-3$ years old, (4) current-years calves. Continued on pp. 156-157. 

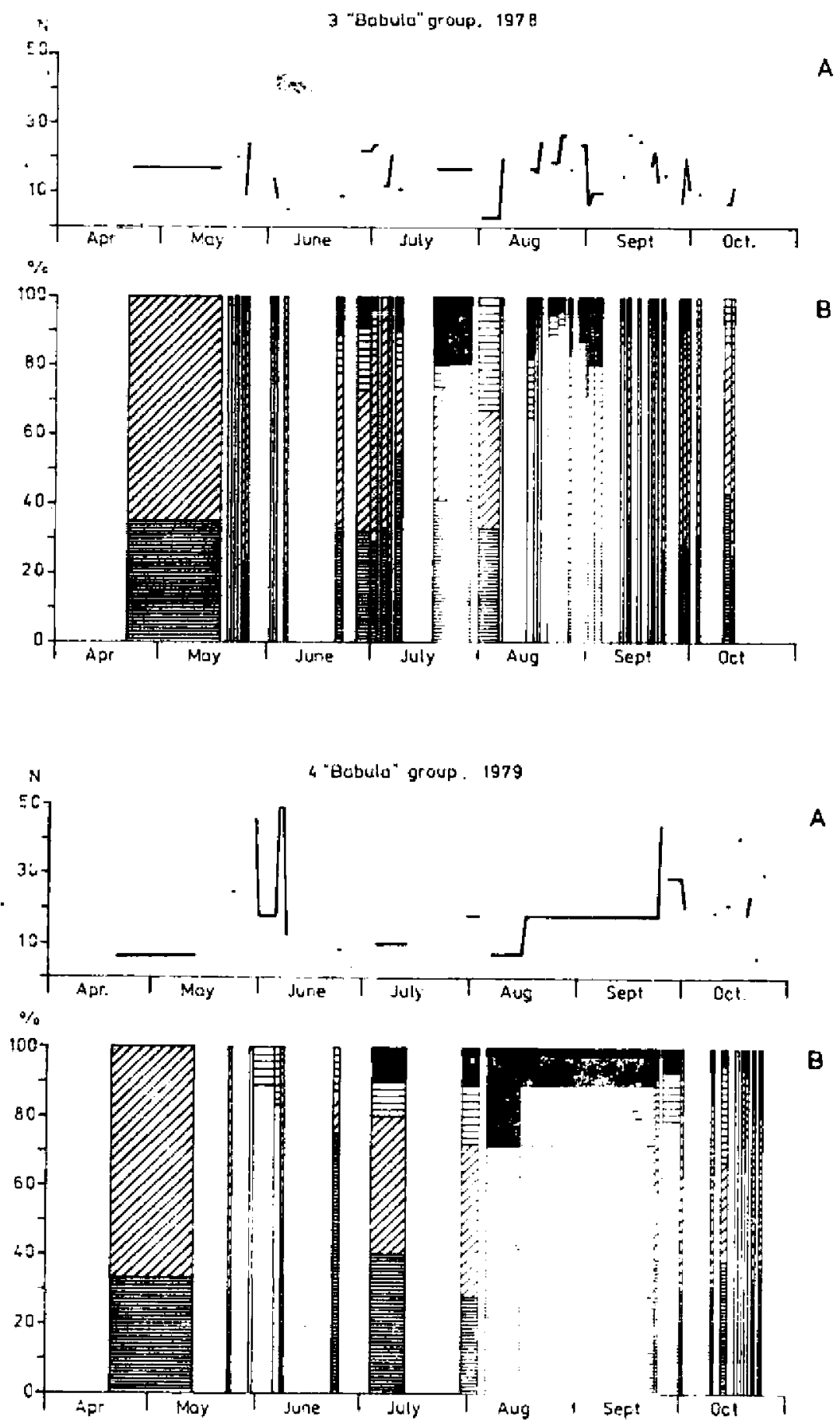

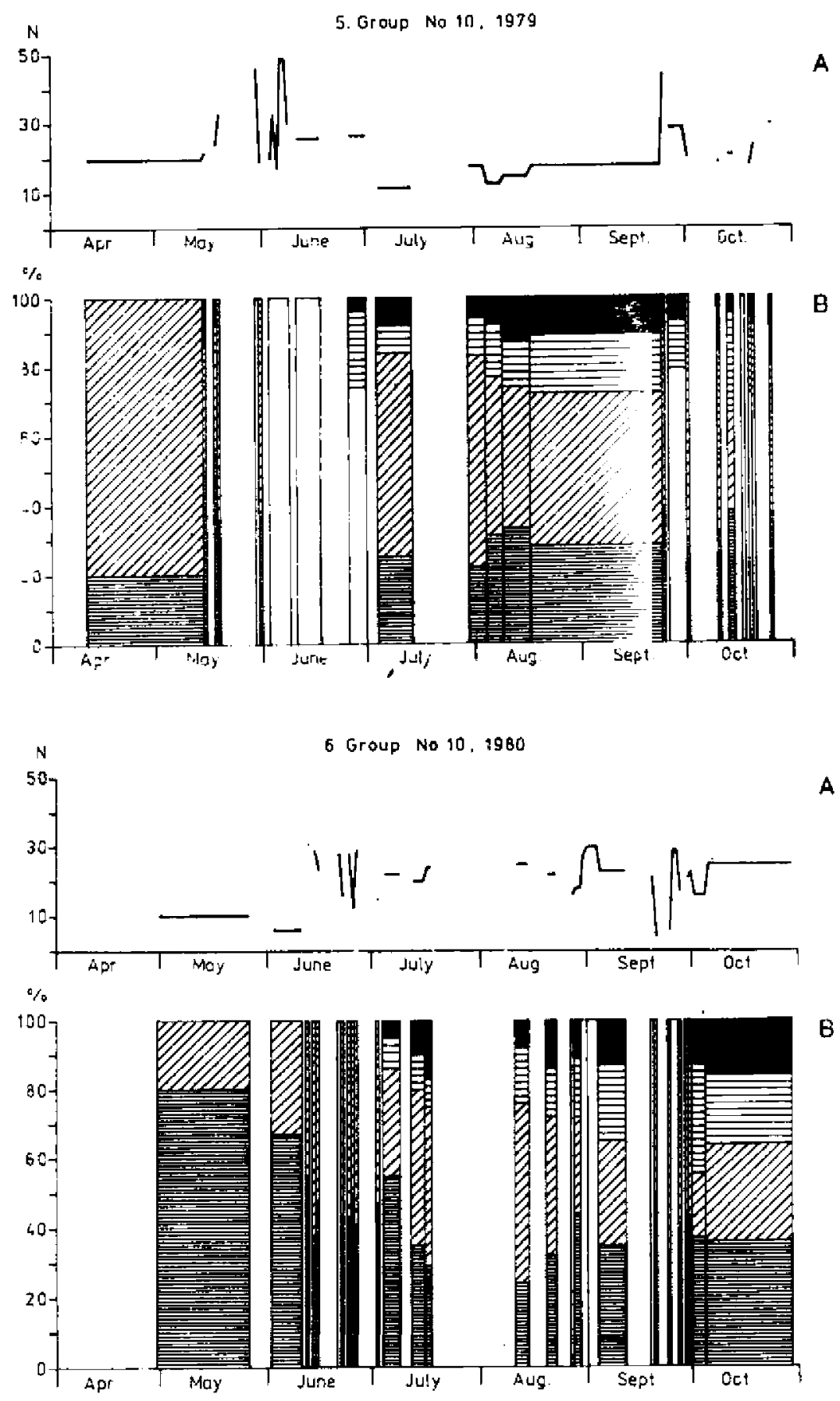

Fig. 2. Concluded 

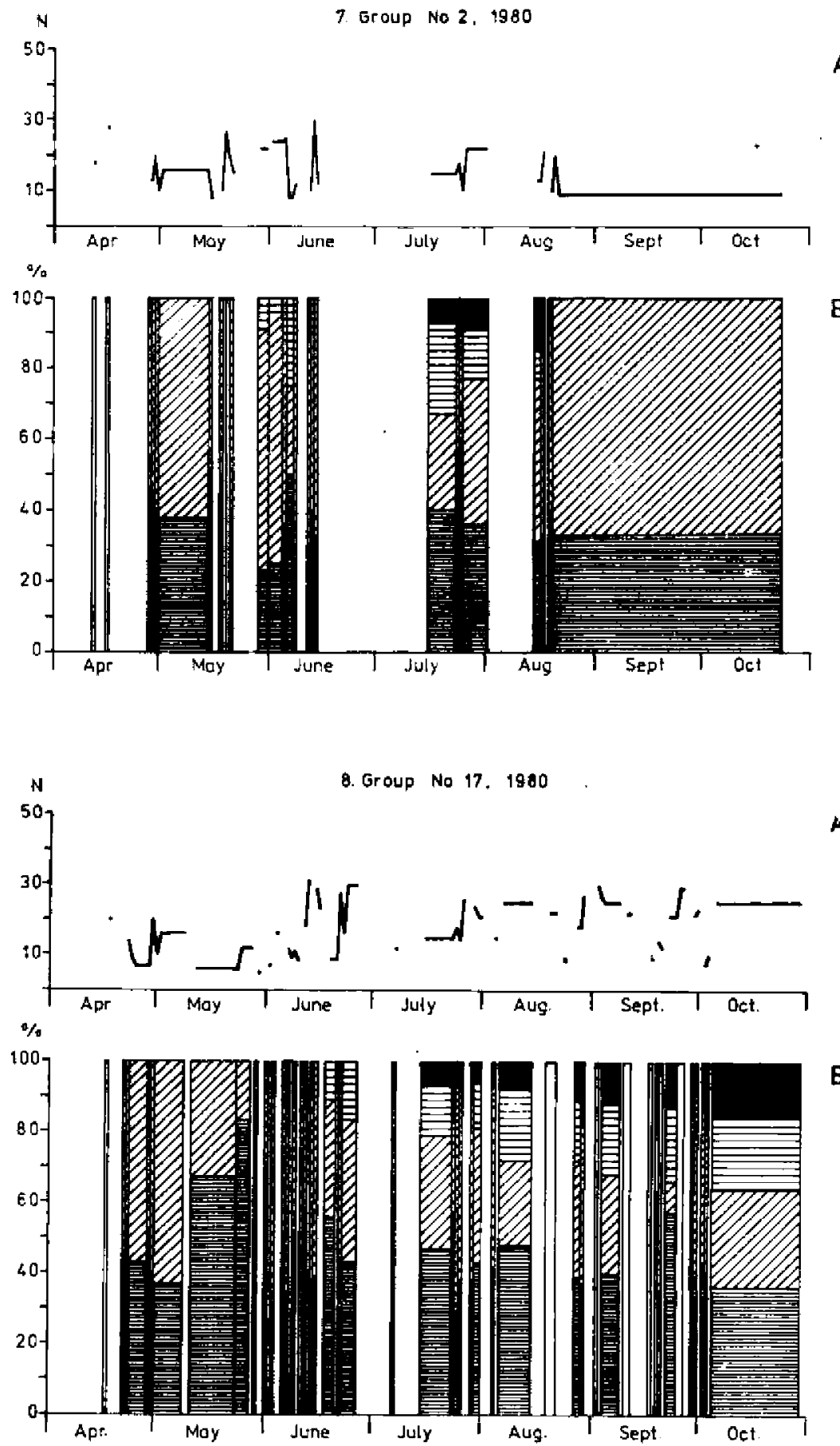
Table 2

Stability of the size of mixed groups of bison in the period without snow cover. Mean values for 8 groups in $1977-1980$.

\begin{tabular}{|c|c|c|c|}
\hline Season & $\begin{array}{l}\text { Number of } \\
\text { individuals } \\
\text { in group }\end{array}$ & $\begin{array}{l}\text { Time (min-max) } \\
\text { of group stability } \\
\text { (days) }\end{array}$ & $\begin{array}{l}\text { Mean time } \\
\text { of group } \\
\text { stability } \\
\text { (days) } \pm S D\end{array}$ \\
\hline $\begin{array}{l}\text { April-May } \\
\text { June-July } \\
\text { August-October }\end{array}$ & $\begin{array}{l}6-27 \\
6-49 \\
3-30\end{array}$ & $\begin{array}{l}3-32 \\
2-11 \\
2-64\end{array}$ & $\begin{array}{r}16.7 \pm 10.3 \\
5.0 \pm 3.0 \\
8.0 \pm 12.5\end{array}$ \\
\hline
\end{tabular}

was much longer than in the period of calving ( $p<0.001)$ and rut $(0.02<$ $p<0.01$ ). No correlation was found between the size of a group and its duration in unchanged composition.

For groups identified on the basis of the same marked individual, no significant difference in the mean group size were found over several years. But if we compare different groups in the same season, then in 1978 the size of group "Pocieszna" significantly differed from the size of group "Babula" $(0.05<p<0.02)$. In 1979 also the group "Babula" and

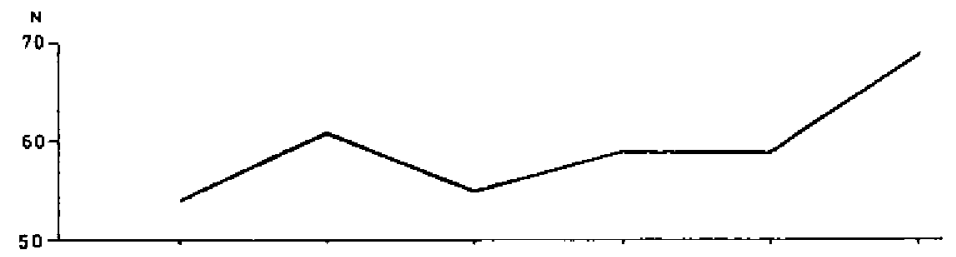

A

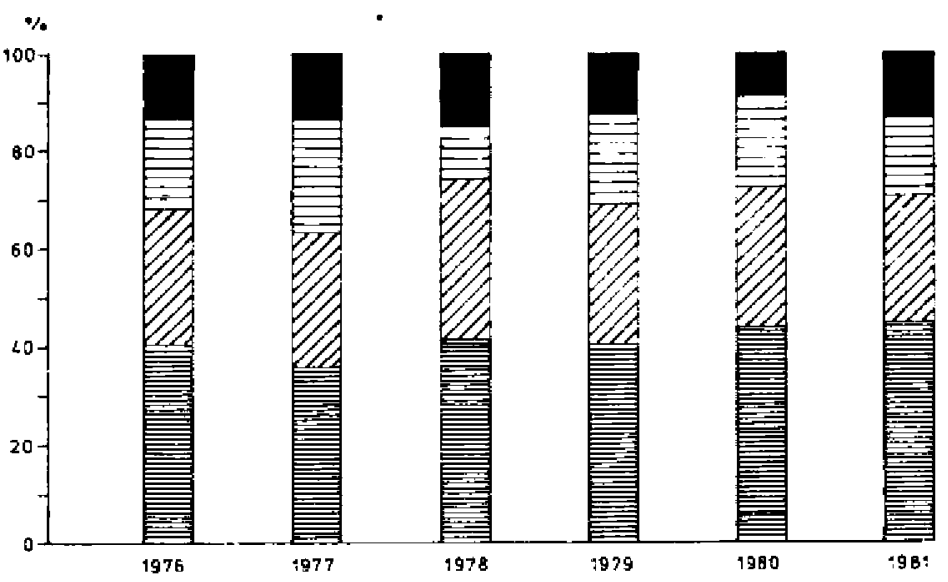

$B$

Fig. 3. Number of individuals (A) and composition (B) of the winter aggregation in forest compartment 422. For explanations see Fig. 2. 
group No. 10 significantly differed in size $(p<0.001)$. In 1980, group No. 2 was significantly smaller than the other groups, which did not differ from each other (Table 1).

Thus, in the period without snow cover the size and structure of the group showed large variation $(\mathrm{CV}=23.5-50)$, whereas in winter variation in aggregation size was irsignificant (Fig. 3). No pattern of changes in the group size and structure was discerned, except for the seasonal appearance of newborn calves and bulls during the rut season.

A mean four-year group size was 17.4 (3-49) individuals. The largest groups were observed in June $\left(\vec{x}^{\prime}=19.7\right)$. They were also most variable. The smallest variation was noted in July $(S D=5)$, which is consistent with the earlier described relative stability of groups (Fig. 4).

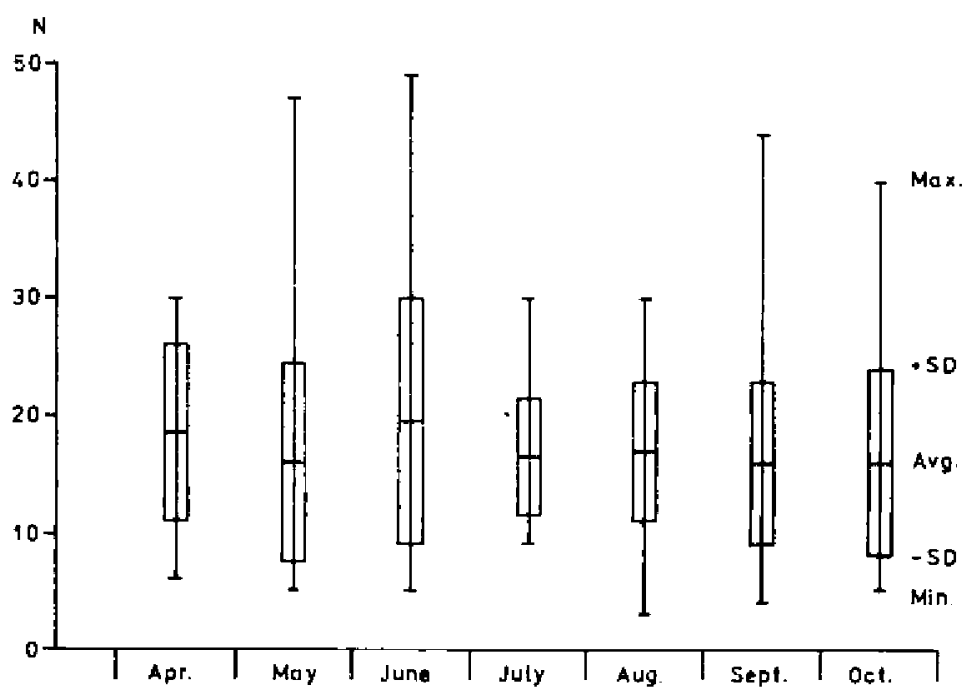

Fig. 4. Mean number of individuals $-(\mathrm{N})$ in a mixed group in 1977-.1980.

\subsection{Co-occurrence of Individuals in Groups}

The co-occurrence of marked individuals in groups was observed during four successive years. In this period they changed age classes. In 1978, a total of 14 individuals were identified (11 were marked, 3 with individual features). They accounted for $25 \%$ of the winter aggregation size. The analysis of data (Fig. 5) shows the following directions of changes: In the first year of observations, nine individuals were frequently observed together (see Section 2, methods) -4 cows, 3 heifers two years old, and 2 bulls two years old (Fig. 5.1). In the following year (1979), seven individuals frequently co-occurred, and they included only 


\subsection{8}

\begin{tabular}{|c|c|c|c|c|c|c|c|c|c|c|c|c|c|c|c|}
\hline$f \mathrm{uv}$ & 5 & 8 & 61 & 4 & & 1 & 4 & 6 & & 0 & & & & 8 & \\
\hline$\delta^{\prime} \mathrm{juv}$ & 1 & 18 & 20 & 13 & 13 & 2 & 9 & 17 & 4 & 7 & 9 & 2 & 2 & & \\
\hline o juv & 9 & 8 & 6 & 25 & 5 & 7 & 19 & 20 & 0 & 10 & 21 & & & & \\
\hline & 13 & 16 & 8 & 28 & 7 & 14 & 21 & 24 & 3 & 9 & & & & & \\
\hline & 12 & 14 & 19 & 24 & 7 & 6 & 18 & 45 & $\theta$ & 13 & & & & & \\
\hline$t^{\mathrm{juv}}$ & 6 & 37 & 34 & 15 & 39 & 32 & 11 & 15 & & & & & & & \\
\hline juv & \begin{tabular}{|l|}
8 \\
\end{tabular} & 35 & $\overrightarrow{B_{i}}$ & 12. & 26 & 35 & 12 & & & & & & & & \\
\hline ad. & $\mathrm{Po}$ & 23 & 23 & $37^{\circ}$ & 30 & 6 & 24 & & & & & & & & \\
\hline ad. & UR & 33 & 28 ! & 59 & 31 & & & & & & & & & & \\
\hline juv & 2 & 48 & 44 & 22 & & & & & & & & & & & \\
\hline ad & $\mathrm{Ba}$ & 43 & 48 & 30 & & & & & & & & & & 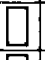 & \\
\hline jur & \begin{tabular}{|l|}
3 \\
\end{tabular} & 51 & 40 & & & & & & & & & & & & \\
\hline & 4 & 68 & & & & & & ㅔ. & & & & & & (11) & \\
\hline & 10 & & & & & & & 血 & & & & & & $\square$ & \\
\hline & & 10 & 4 & 3 & & 2 & & $\mathrm{Po}$ & 8 & & & & & & \\
\hline
\end{tabular}

2. 1979

\begin{tabular}{|c|c|c|c|c|c|c|c|c|c|c|c|c|c|c|}
\hline$\delta^{\circ}$ atf. & 5 & 1 & 1 & 1 & & $0 ! 2$ & & & & & 0 & 1 & 1 & 0 \\
\hline 800 & 6 & 3 & 4 & 2 & & \begin{tabular}{l|l}
1 & 1
\end{tabular} & & & & & 3 & 1 & 3 & \\
\hline ad & 3 & $15 \mid$ & 4 & 5 & & 3 & 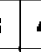 & & & & & 7 & & \\
\hline ad. & $\mathrm{Po}$ & 21 & 5 & 88 & & $0 \mid 8$ & & & & & & & & \\
\hline s juv. & 12 & 197 & & \begin{tabular}{l|l}
8 & 1 \\
\end{tabular} & & $11^{-1}$ & & & & & & & & \\
\hline of ad. & 13 & $39 \mathrm{i}$ & 0 & 8.7 & & 99 & & & & & & $\square$ & 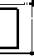 & \\
\hline od. & 2 & 363 & 3 & 619 & & 5 & & & & & & & & \\
\hline of ad. & 4 & $3 5 \longdiv { 2 }$ & & 53 & & 21 & & & & & & & & \\
\hline$\delta^{\circ}$ ad. & 1. & $71^{3}$ & & 0.2 & & & & & & & & & & \\
\hline 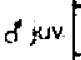 & 8 & 454 & & 72 & & & & & & & & & & \\
\hline Q jov. & 9 & \begin{tabular}{l|l}
77 \\
\end{tabular} & & 16 & & & & & & & & & & \\
\hline$q$ art. & UA & 25 & & & & & & & & & & & & \\
\hline ad & $\mathrm{BO}$ & & & & & & & & & & & & & \\
\hline & & & & & & & & & & & & (1!) & & \\
\hline & & $0 B$ & al & $\mathbb{R}$ & & 811 & & & & & & & & \\
\hline
\end{tabular}

five individuals from the preceding year (Fig. 5.2). In 1981 none of the primarily co-occurring individuals was in the group of frequently co-occurring animals. This imples that changes in association among individual animals can depend on:

1) Disappearance of the mother-calf relationships at an age of $2-3$ 


\subsection{0}

\begin{tabular}{|c|c|c|c|c|c|c|c|c|c|c|c|c|c|c|c|}
\hline \& juv. & 12 & & 0 & 0 & 0 & 0 & 0 & 0 & 0 & 0 & 0 & 0 & 0 & & \\
\hline dad & 6 & 0 & 0 & 0 & 0 & 0 & 0 & 0 & 0 & 0 & 0 & 0 & 0 & & \\
\hline 6 od & 5 & 5 & 4 & 5 & 4 & 5 & 3 & 0 & 6 & 0 & 0 & 0 & & & \\
\hline$q$ ad. & $\mathrm{Po}$ & 3 & 12 & 0 & 13 & 5 & 3 & 0 & 7 & 1 & 1 & & & & \\
\hline$q$ ad. & 13 & 3 & 13 & 10 & 3 & 4 & 2 & 7 & 1 & 4 & & & & & \\
\hline$q$ ad. & 2 & 13 & 4 & 7 & 6 & 4 & 2 & 10 & 1 & & & & & & \\
\hline$\delta$ ad. & 8 & 16 & 15 & 15 & 16 & 7 & 9 & 0 & & & & & & & \\
\hline$q$ ad. & 9 & 9 & 6 & 3 & 12 & 3 & 2 & & & $\square$ & & & & & \\
\hline of ad & 1 & 22 & $20^{\prime}$ & 21 & 13 & 96 & & & & & & & & & \\
\hline$q$ ad. & $\mathrm{Ba}$ & 31 & 27 & 29 & 18 & & & & & & & & & & \\
\hline q ad. & 4 & 51 & 54 & 39 & & & & & Џ & & & $\square$ & & & \\
\hline$q$ ad & UR & 59 & 45 & & & II & III & & {[} & & ] & & & & \\
\hline$q$ ad. & 10 & 56 & & & & in & III & & $\bar{\square}$ & & $\square 1$ & 口 & & & \\
\hline$q$ ad. & 3 & & & & & & III & & $\square$ & $\square$ & & & & & \\
\hline & & 3 & 104 & $\mathrm{JR}$ & 4 & $\mathrm{Ba}$ & 1 & 9 & 8 & 2 & $13 \mid \mathrm{F}$ & $\mathrm{Po}$ & 5 & 61 & 12 \\
\hline
\end{tabular}

\section{1981}

\begin{tabular}{|c|c|c|c|c|c|c|c|c|c|c|c|c|c|c|c|}
\hline$\delta^{\prime} \mathrm{cd}$ & 12 & 0 & 0 & 0 & 0 & 0 & 0 & 0 & 0 & 0 & 0 & 0 & 0 & 0 & \\
\hline$d \mathrm{~cd}$ & 6 & 0 & 0 & 0 & 0 & 0 & 0 & 0 & 0 & 0 & 0 & 0 & 0 & & \\
\hline$\delta$ od & 1 & 1 & 0 & 0 & 0 & 0 & 0 & 0 & 1 & 0 & 3 & 0 & & & \\
\hline fod ad & 8 & 3 & 0 & 0 & $D$ & 6 & 1 & 2 & 0 & 0 & 0 & & & & \\
\hline tod & 5 & 5 & 2 & 3 & 5 & 1 & 1 & 4 & 2 & 2 & & & & & \\
\hline o od & Po & 7 & 7 & 4 & 6 & 2 & 1 & 3 & 4 & & & & & & \\
\hline god & 4 & 10 & 7 & 9 & 5 & 6 & 0 & 2 & & & & & & & \\
\hline$q$ ad. & $\mathrm{Ba}$ & 20 & 7 & 4 & 6 & 5 & 0 & & & & & & & & \\
\hline q ad. & 9 & 6 & 11 & 11 & 7 & 4 & & & & & & & & & \\
\hline q ad. & 10 & 15 & 7 & 7 & 3 & & & & & & & & & & \\
\hline qad. & UP & 18 & 21 & 15 & & & & & & & & & & & \\
\hline 9 ad. & 13 & 15 & 16 & & $\bigsqcup$ & & & & & & & & & & \\
\hline q ad. & 2 & 24 & & & & & & & & & & & & & \\
\hline$g$ ad & 3 & & $\underline{W}$ & & $=$ & & & & & & & & & & \\
\hline & & 3 & 2 & 13 & UR & & 9 & $\mathrm{Ba}$ & 4 & Po & 5 & 8 & 1 & & 12 \\
\hline
\end{tabular}

Fig. 5. Co-occurrence of marked individuals. Figures in the left part of the diagram denote the frequency of co-occurrence. The right part represents the same in graphical form, using a seven-degree scale of co-occurrence. Other symbols are as follows: juv - young 2-3 years old; ad - adult animals, older than 4 years; cal - calves up to one year old; $\mathrm{Ba}$ - "Babula", adult female name; Po "Pocieszna", adult female name; UR - adult female; other numerals are identification number of individual animals. 
years. For example, cow 10, the daughter of "Babula", at an age of fcur years was occasionally in the mother group. Bull 12, the son of "Pocieszna", already in the second year of life occurred in another group than his mother, which is a rare event, and at an age of two years he lost the contact with his mother group.

2) Gain or loss of leadership in the group. The loss of leadership may be a result, among other things, of the aging of a cow, as it was the case of "Babula", known to be the leader for many years. Since an age of 21 years this cow did not give birth for two successive years (1981 and 1982). At that time she lived mostly alone on a small home range. But at an age of 23 years she gave birth to a calf and raised it. At that time she was again observed in mixed groups but her leadership was no more clear cut. In 1981, adult cows 2,10 , and UR became leaders in different groups.

3) The effect of age on the presence of bulls in mixed groups. Over the whole growing season, 2--3-year-old bulls were encountered in mixed groups in about $97 \%$ of the observations. The proportion of bulls more than 4 years old decreased in mixed groups and increased in the groups of bulls in the non-rutting period.

\subsection{Group as a Structural Unit in Bison Population}

The preceding sections analysed factors determining changes in the composition of mixed groups, which were related to seasonal changes in the biology of the species (calving and rutting periods) and to structural changes in the population (maturation, changes in social rank of individual animals). Despite these changes, the group remained a permanent structural unit of the bison population.

Taking group No. 10 as an example, the proportion of marked individuals was analysed in three successive years (Fig. 6). It has been found that the most stable components of the group were adult cows $(2,3,4$, $9,10,13$, UR, Pocieszna, Babula), who occurred in this group in successive years, though in variable combinations. This implies that the annual restoration of groups after the period of winter aggregation is not a process in which individuals join each other at random. Some persistent associations are likely to be involved here, with adult cows being the core of the developing group. Two adult bulls ( 1 and 5$)$ were less often present in the group. Bull 5 more frequently in 1979, whereas bull 1 in 1980. Two young bulls ( 6 and 12) also rarely appeared in the group only in the first two years, and as adults, in 1980, also rarely. Amo.ng heifers, 9 and 13 occurred more frequently in the group in the 
second year of observation, and heifer 3 appeared more frequently in the first year and in the third year (already as adult). As already noted, statistically significant differences occurred in the structure of group No. 10, concerning the proportions of calves, young, and cows in successive years (Table 1 ).

In the period without snow cover, frequent changes were observed in groups. They included exchange of individuals during encounters of $2-3$ groups foraging in the same area. On such occasions, one common group, formed temporarily, can be maintained for $1-3$ days (47, 49 individuals, see Figs. 3.2 and 3.6). Then such a group splits into $2-3$ smaller groups differing in their composition from the original groups.

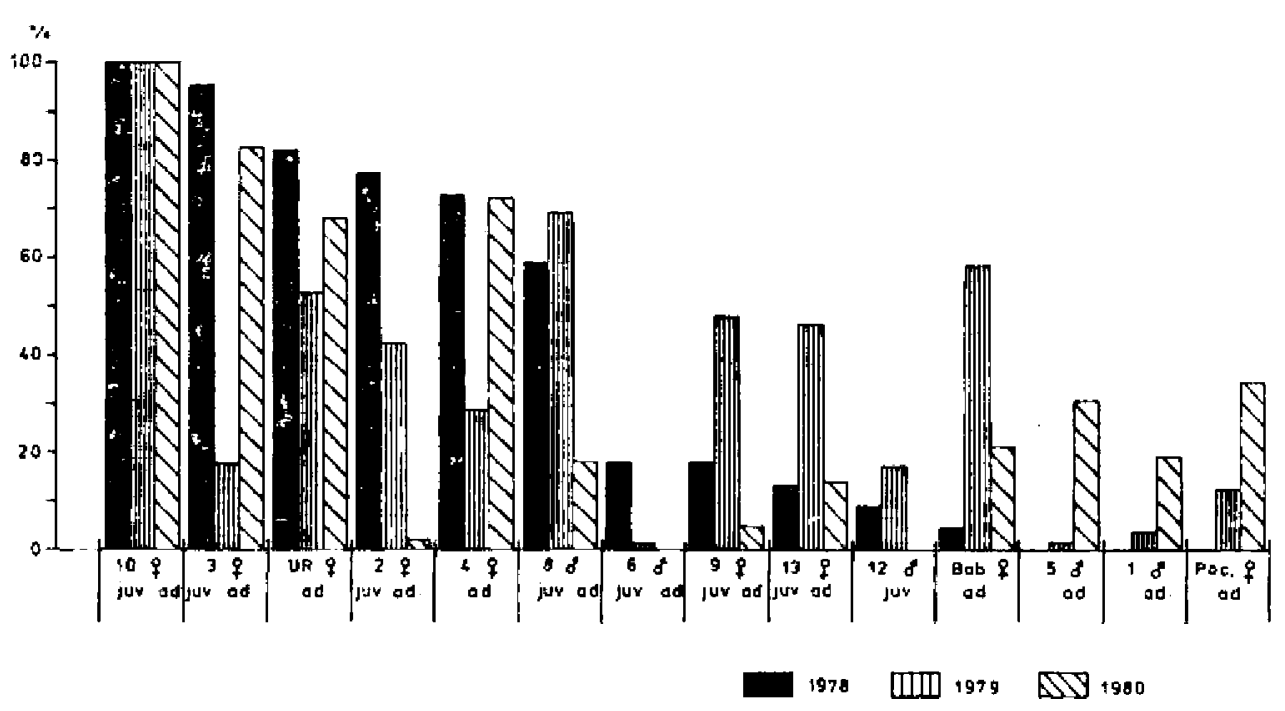

Fig. 6. Frequency of occurrence (as percentage of all observations $N=275$ ) of marked individuals in group No, 10 in 1978-1980. The animals are arranged according to their frequency of occurrence in this group in 1978.

During four years of continuous observations of groups $(n=1181) 95$ encounters were recorded. Their number could even be higher as $2-3$ groups foraging in one forest compartment (ca $100 \mathrm{ha}$ ) were frequently noted.

Another occasion for an exchange of individuals occurs when a cow with a calf join an "alien" group. In the rutting period, adult bulls joi.l groups, accounting for changes in their composition. During spontaneous mixing of groups and exchange of their members no aggression against newcomers was observed.

To sum up, we can state that mixed groups, in addition to groups of 
bulls not analysed in this paper, are the natural form of the occurrence of bison populations in the period without snow cover. The grcup is characterized by its size and structure. Both these parameters largely vary, depending among other things on the rhythm of seasonal biological processes (calving and rutting periods) and other factors such as the overlap of home ranges, frequent encounters of groups, and exchange of group members. The least persistent associations exist among the young. They are maintained at most for one season. Young bulls most frequently change groups. Groups are restored year after year, usually around adult cows aggregated at the leader cow.

\section{SEASONAL CHANGES IN HOME RANGES OF MIXED GROUPS}

The mixed groups originating from one winter aggregation under study occupied an area of about 6180 ha (Fig. 1). Home ranges of individual mixed groups largely overlapped, as the mean area searched by a single group in the period without snow cover was $4700 \pm 720$ ha $(4600-5600$ ha). A mean monthly home range of a group was $2100 \pm 886$ ha. The size of a searched area varied from season to season. In April, at the beginning of the growing season, and at the end of October, group home ranges had smallest sizes (Table 3). The largest mean home ranges were established in May (2802 ha), and the difference was statistically significant as compared with the other months $(0.05<p<0.02)$. The home ranges occupied in other months from April to October did not show statistically significant differences in their sizes. Home ranges of individual groups showed some differences in each month, resulting in a rather high $C V$ of the mean group home range (24.5-63.4).

This observed variation in the group home range was confirmed by the data on searching distance measured by average daily routes (Table 3 ). The average daily route covered by group over the period without snow cover for 4 study years was $2034 \mathrm{~m} \pm 1476$. The lowest value was noted in August, 1977, when the group moved only $140 \mathrm{~m}$ a day, and the highest one in May, 1980 , amounting to $11,750 \mathrm{~m}$. Mean values varied in different months, but significant differences occurred only in May, when the mean value was $2438 \mathrm{~m}$ a day $(0.002<p<0.001$, except for June; Tab. 3). Penetration distances of different groups were variable, the average monthly $C V$ reaching $60.3-79.9$ (Table 3 ). Presumably movements of groups change with phenological cycles in vegetation growth. Monthly series provide only an approximate picture of changes in the intensity of movements (see similar values of the range of movements in May and June, Table 3). 
Seasonal variation in the range of movements of mixed groups is shown in Figure 7. In April, these groups remained in a small area, close to the feeding site, and their home ranges largely overlaped (Fig. 7.1). Individual differences in the size of home ranges of particular groups were observed. In May, as already noted, the groups searched larger areas, and the size of group home range was least variable $(C V=24.5$, Table 3). In May groups were also widely dispersed. They moved almost over the whole study area at that time (Figs. 7.2 and 7.3). For example, in May 1978 two groups started their penetration in distant, isolated parts of forest but in the end of May they were foraging on common area and their ranges overlapped (Fig. 8). In May, 1980, four groups were observed concurrently. They also first searched distinct parts of the forest, and only in the third ten-day period of May their home ranges overlapped.

Table 3

Mean monthly home ranges (in ha) and mean daily movements of mixed groups (in $\mathrm{m}$ ).

\begin{tabular}{|c|c|c|c|c|c|c|c|c|}
\hline \multirow{2}{*}{ Month } & \multirow{2}{*}{$\begin{array}{l}\text { No. of } \\
\text { groups } \\
\text { observed }\end{array}$} & \multirow{2}{*}{$\begin{array}{l}\text { No. of } \\
\text { observa- } \\
\text { tions }\end{array}$} & \multicolumn{3}{|c|}{ Home range, ha } & \multicolumn{3}{|c|}{ Daily routes, m } \\
\hline & & & $\overline{\boldsymbol{x}}$ & SD & $\mathrm{CV}$ & $\bar{x}$ & $S D$ & $\mathrm{CV}$ \\
\hline April & 6 & 71 & 1460 & 925 & 63.4 & 1673 & 1336 & 79.9 \\
\hline May & 9 & 156 & 2802 & 687 & 24.5 & 2438 & 1921 & 78.8 \\
\hline June & 10 & 150 & 1881 & 761 & 40.4 & 2268 & 1469 & 64.8 \\
\hline July & 4 & 46 & 2045 & 542 & 26.5 & 1933 & 1385 & 71.2 \\
\hline August & 8 & 137 & 2101 & 554 & 26.4 & 2000 & 1250 & 62.5 \\
\hline September & 6 & 120 & 1742 & 965 & 55.4 & 1603 & 967 & 60.3 \\
\hline October & 4 & 53 & 1363 & 668 & 49.0 & 1725 & 1189 & 689 \\
\hline
\end{tabular}

In June, the groups moved toward the central part of the study area, and the size of their home ranges declined. There were individual differences in home range size among different groups in June of the same year and also from year to year $(C, V=40.4)$, and home ranges largely overlapped (Fig. 7.4).

In July groups remained approximately in the same area as in June, and their home ranges largely overlapped.

In Augusts of all the study years, the groups concentrated in northern part of the study area, and their home ranges overlapped almost totally, for example, in August of 1979, when two groups were observed concurrently (Fig. 7.6) or in August of 1980, when four groups were observed. The sizes of home ranges of different groups in August were similar within year and different between years.

In September, like in August, the mixed groups concentrated in northern part of the study area. The size of September home ranges largely varied from year to year $(\mathrm{CV}=55.4)$, and they largely overlapped (Figs. 7.8 and 7.9 ). 
Fig. 7. Spatial distribution of mixed groups in the study area in different months. From one to four groups were observed in the same compartments, thus, one-fourth of forest compartment area corresponds to the presence of one group in a given compartment. The number of observations of a group in the same compartment ranged from 1 to 10 . The maps are selected from the complete set of records and the months with a large number of observation are presented. If there were differences among the same months in different years, all these maps are shown, and if not, one map with the highest number of observations is shown. 


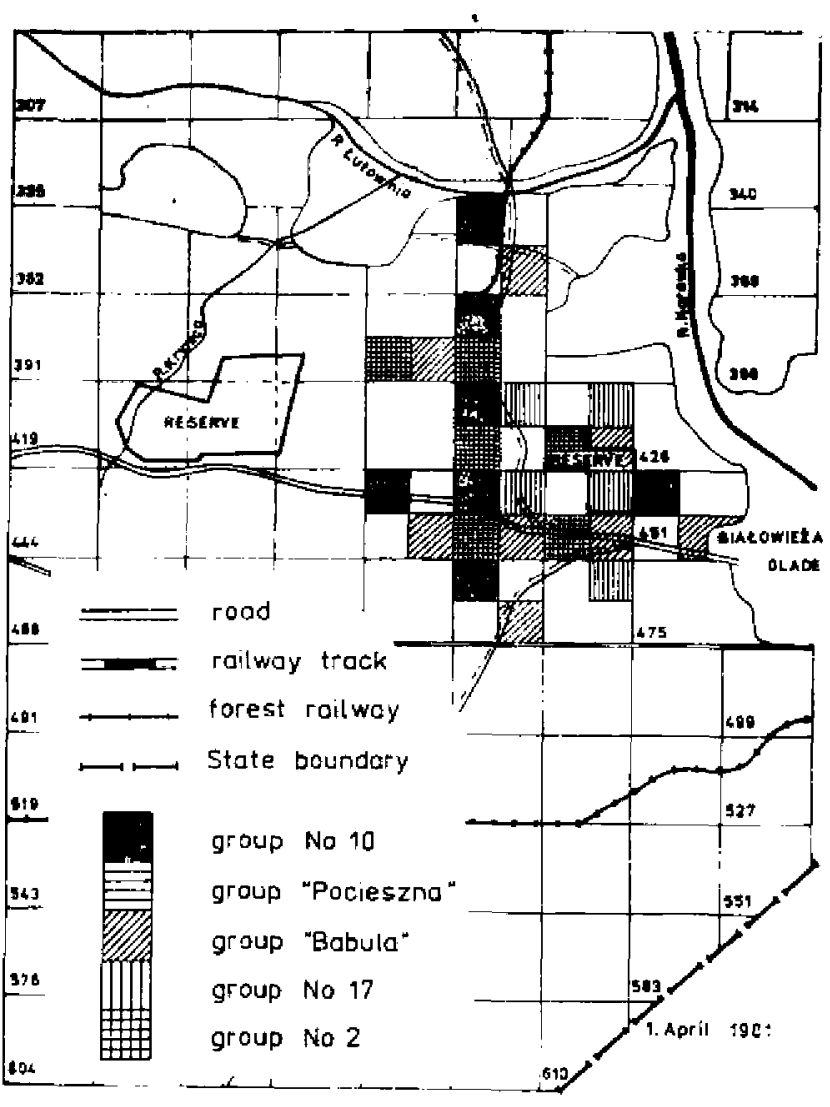

号 

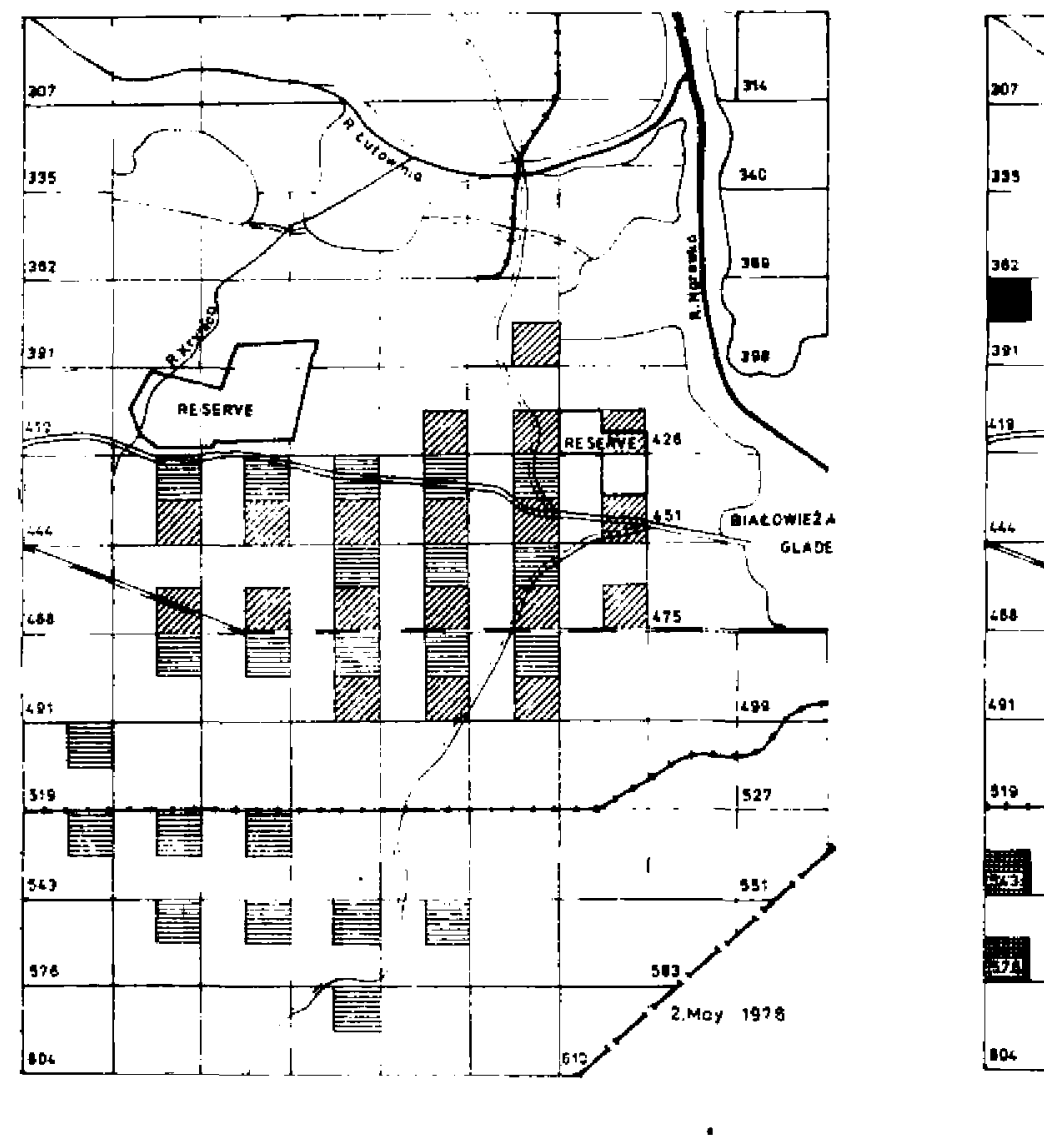

Fig. 7. Continued. 


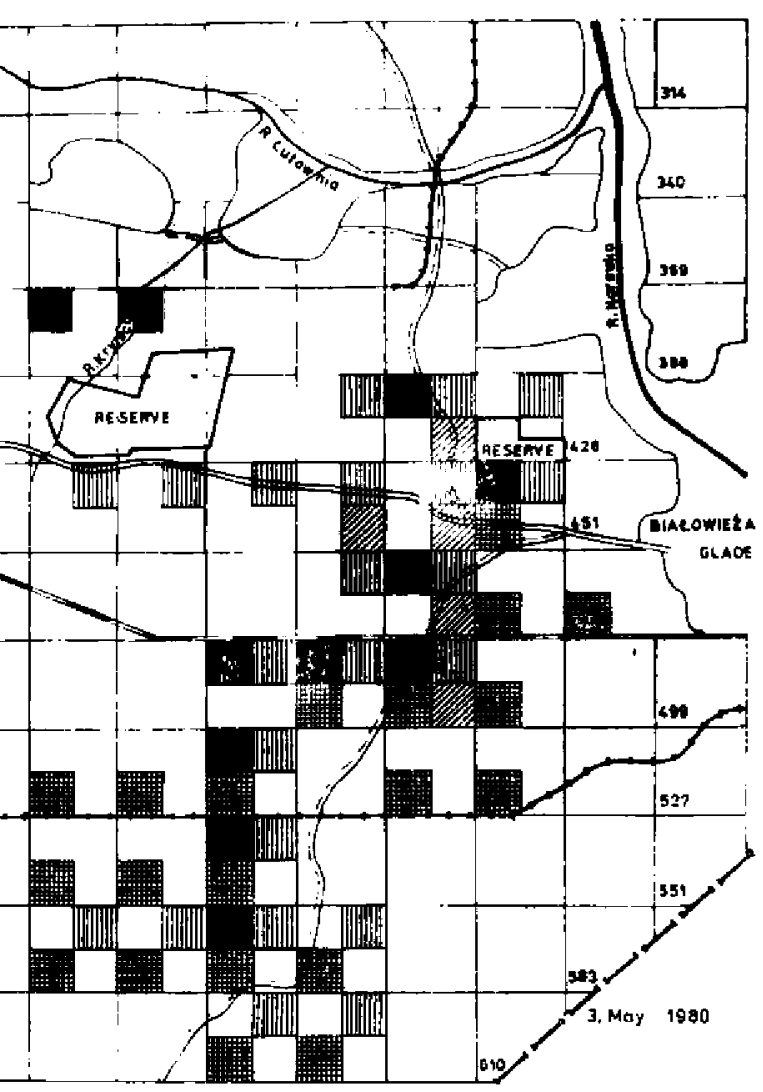

可 


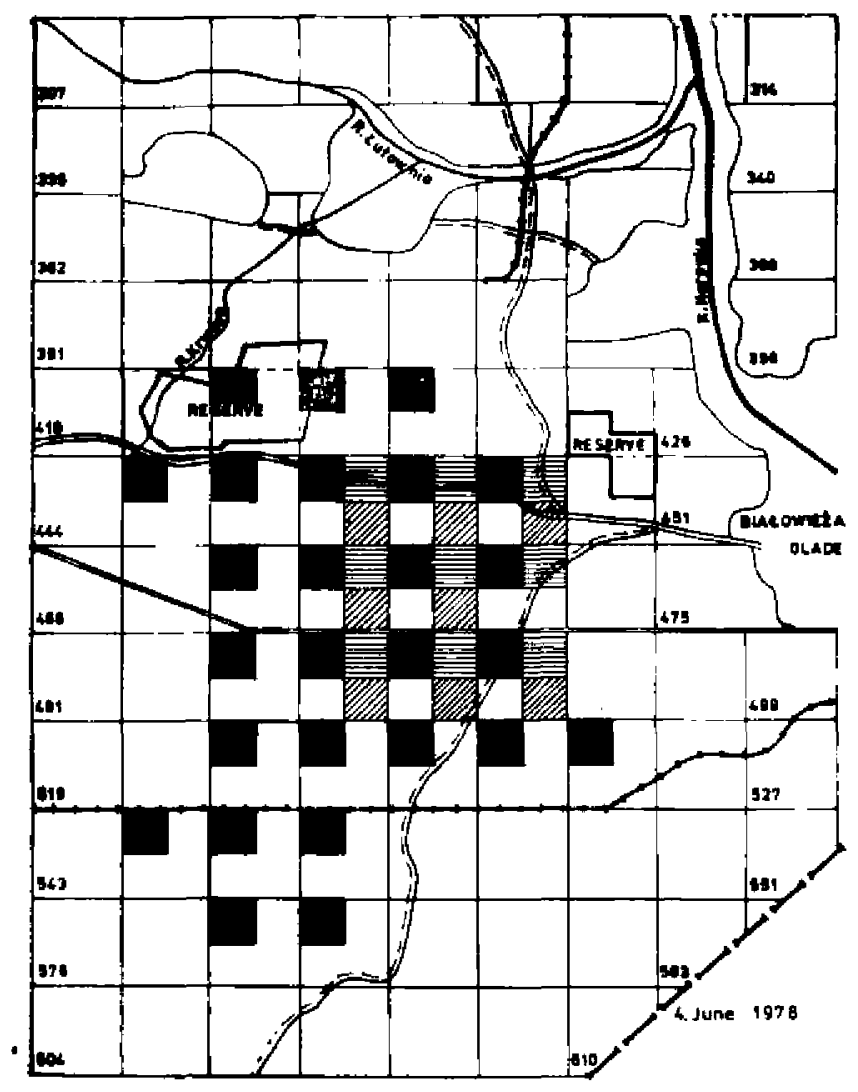

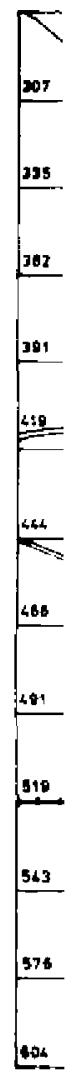

Fig. 7. Continued. 
品

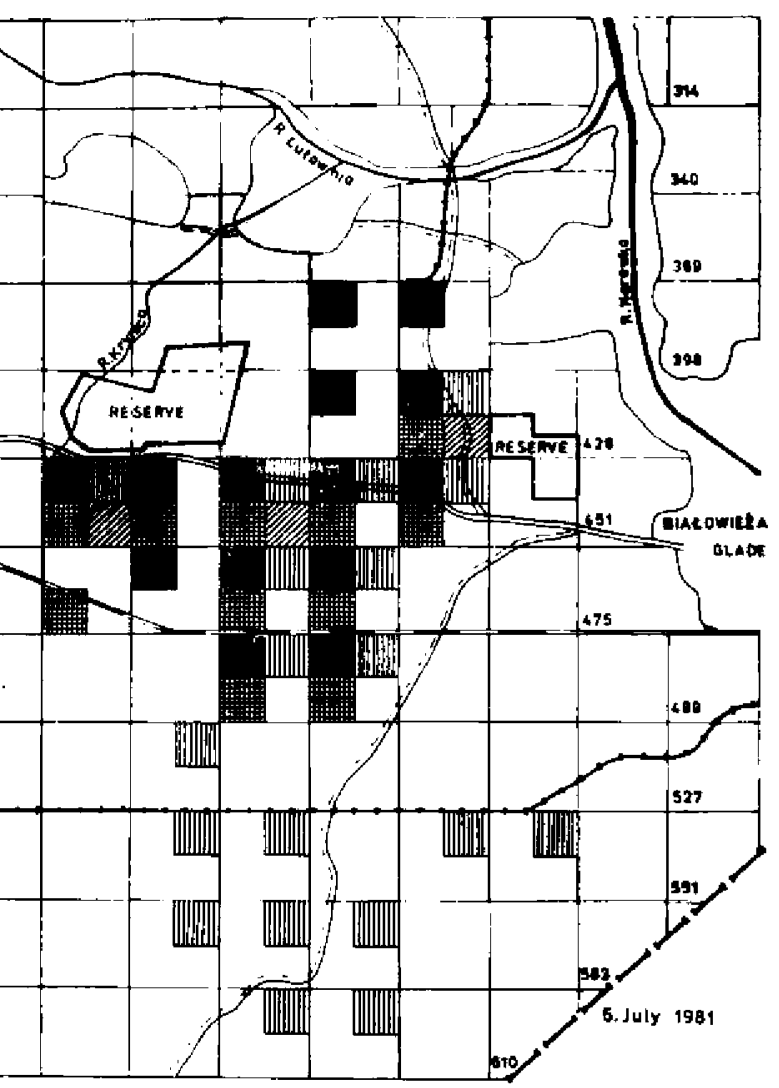



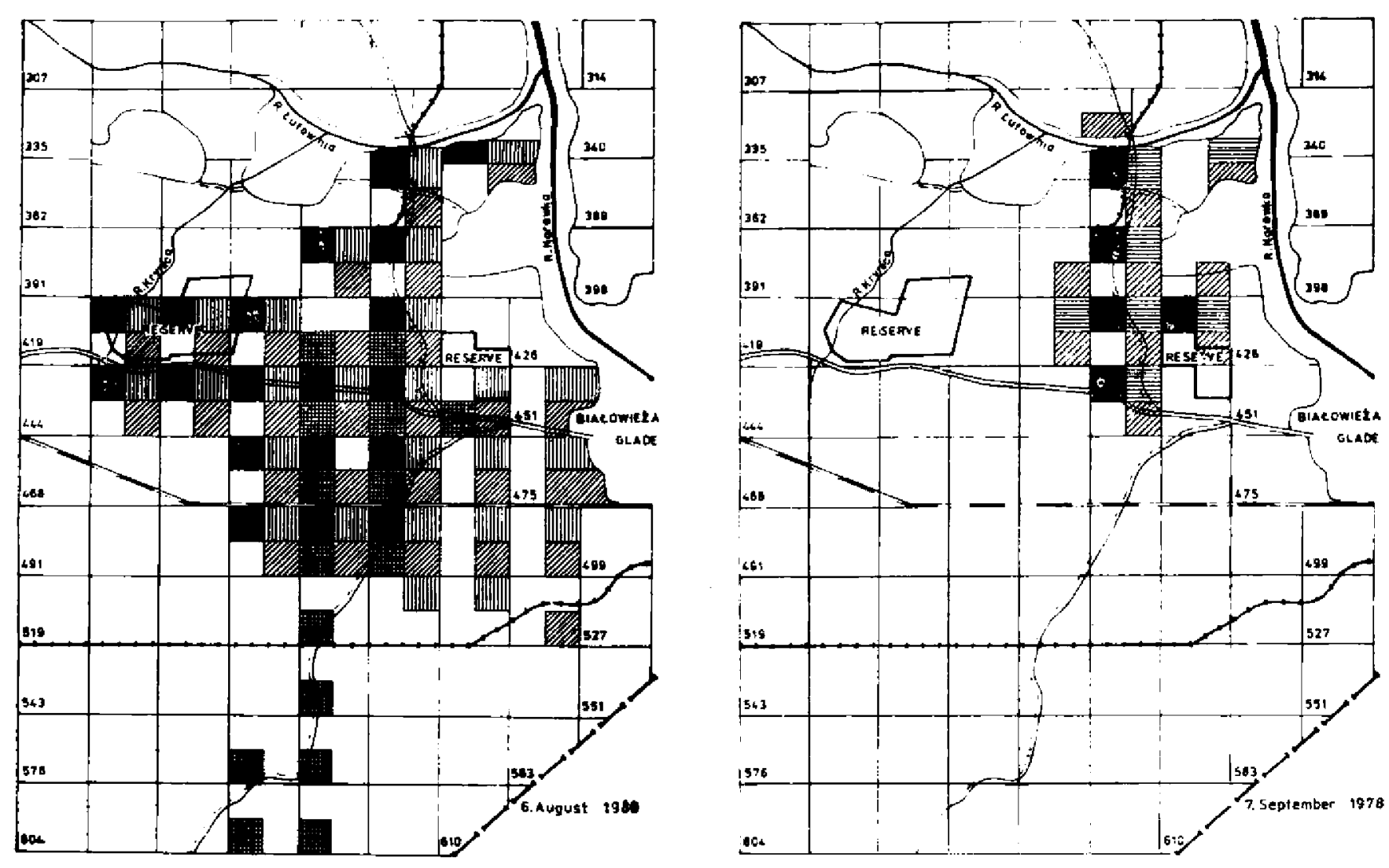

Fig. 7. Continued 

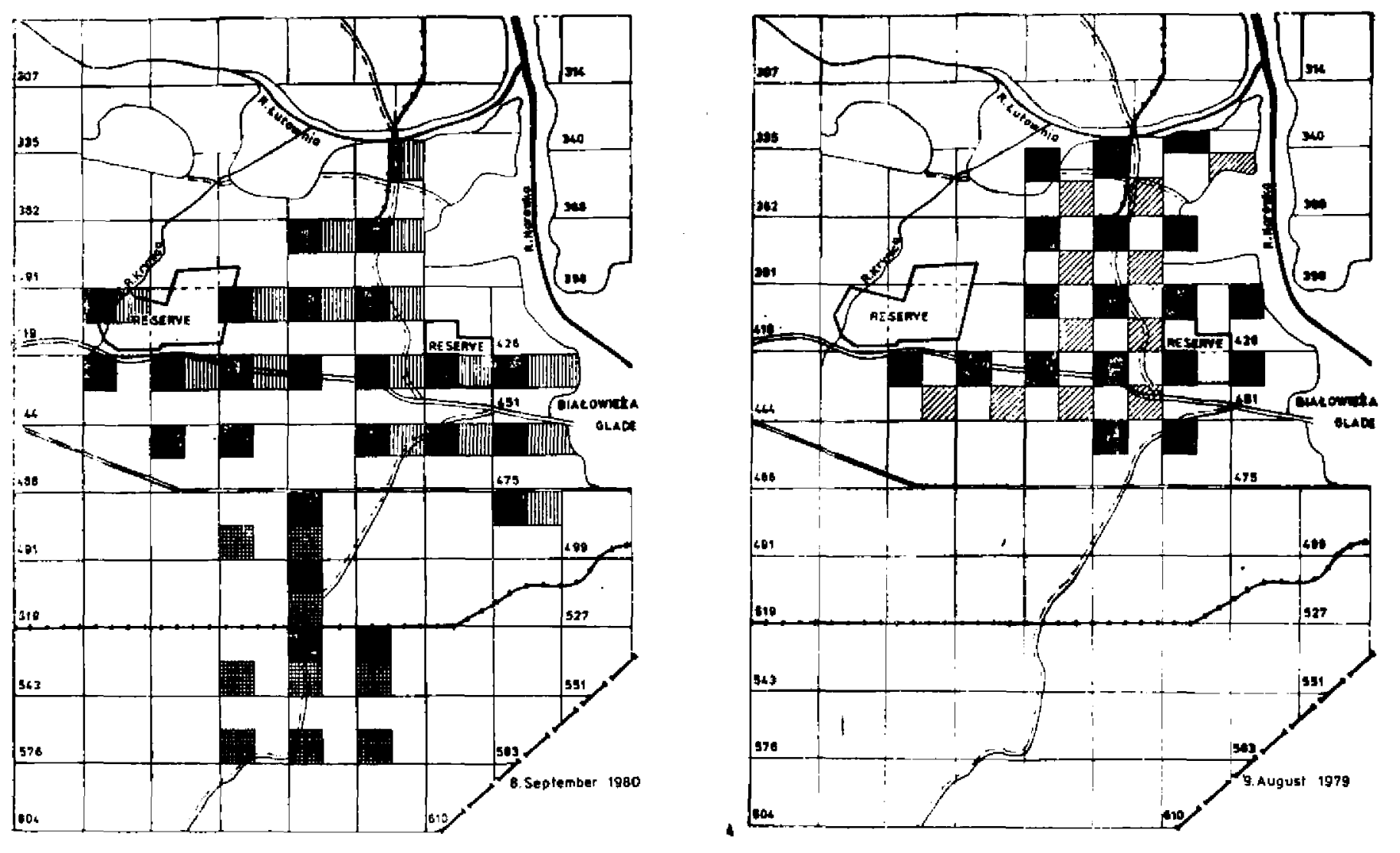

Fig. 7. Concluded. 
It follows from this that the size of group home ranges and the range of group movements vary in different periods of the growing season and from year to year, this being most probably related to variation in the habitat quality in terms of food, which depends on variable climatic factors.

Movements of bison groups are mostly related with foraging activity, except for specific cases such as movements of bulls in the rutting period. Examples of foraging movements of mixed groups are shown in Figure 8 . The routes of movements indicate a rotative character of habitat utilization. The utilization of small preferred patches of the forest, covering $100-200$ ha, takes at most $7-10$ days. Groups returned to the same grazing sites after several to a dozen or so days. The mean time

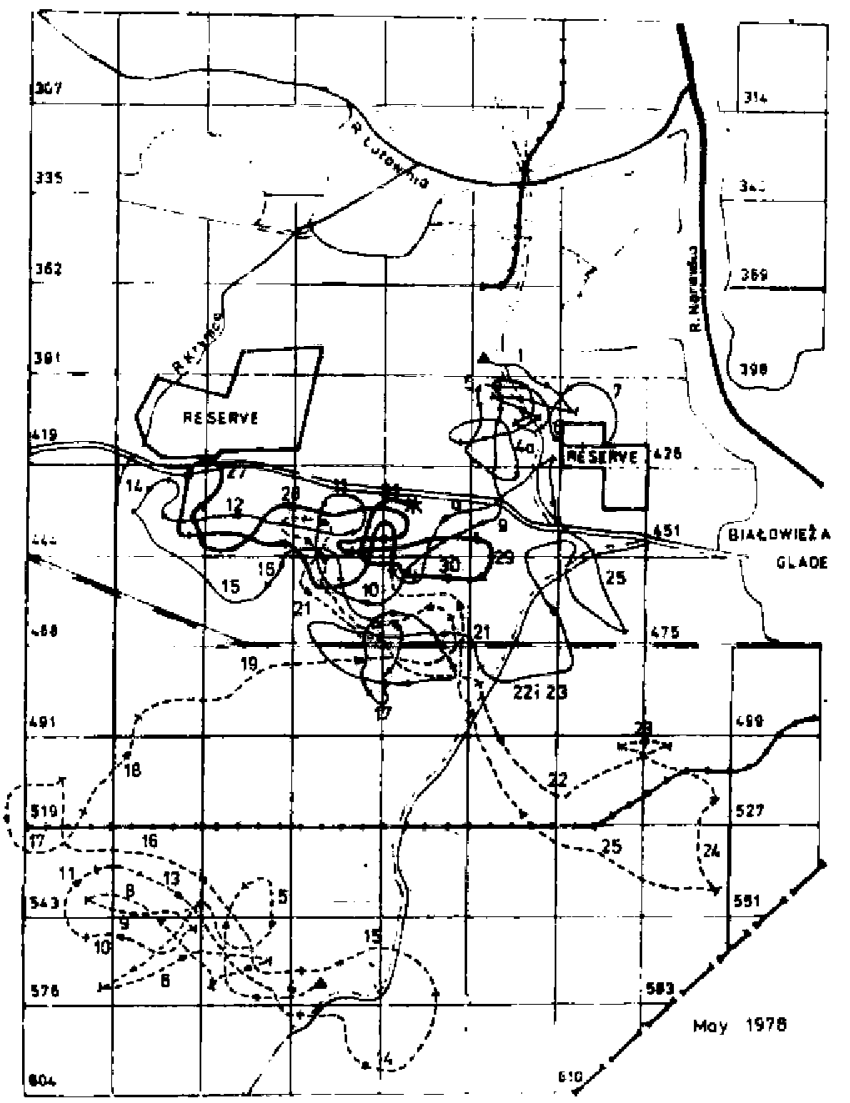

Fig. B. Routes of movements of two mixed groups, "Babula" and "Pocieszna" in May of 1978 .

Symbols: filled triangle - beginning of the route, asterisk - end of the route, arrow - direction of movement, continuous line - route of the group "Babula", broken line - route of the group "Pocieszna", thick line - common route of the two groups. Figures denote days of the month. 

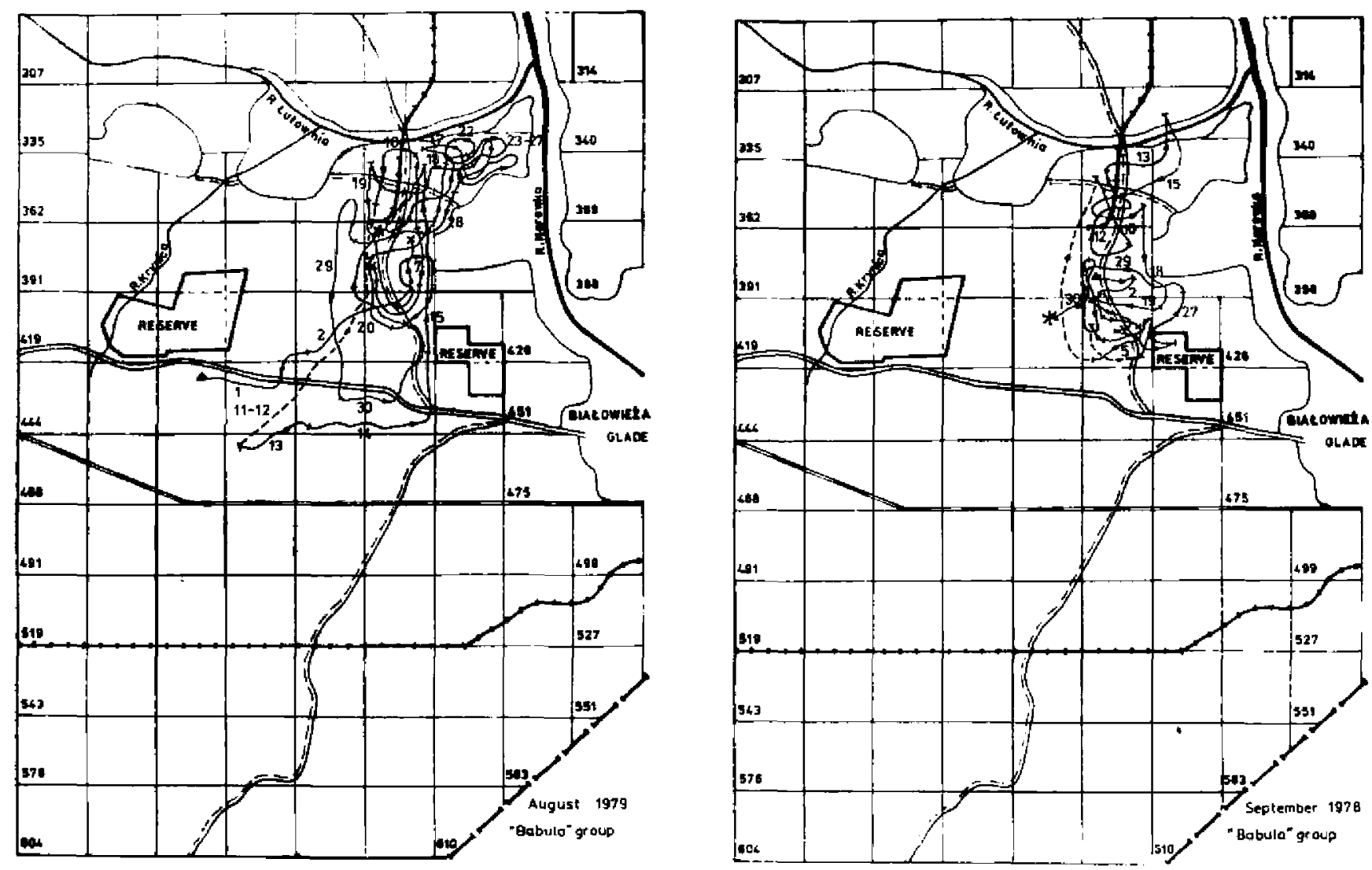

Fig. 9. Routes of movements of two mixed groups, "Babula" in seiected months of two years. For explanations see Fig. n. 
of the return of a group to the same site was 6.6 days, ranging from 2 to 28 days. The most frequent returns were noted in July (4.4 days), then in May and June (5.7 and 5.4 days, respectively), and least frequent i.. April, August, and September (7.2, 7.7, and 11.3 days, respectively).

Figure 10 shows a comparison of home ranges of a group with the same leading cow in corresponding months of different years. For example, group "Babula" moved in Junes of the four study years over similar parts of the forest, located in the centre of the study area. In 1979 and 1980, the home range of this group was larger than in the other years. In Augusts of the four study years the same group moved in northern part of the study area, and its home range was larger in 1979 and 1980 than in 1977 and 1978. Groups with another marked cow (No. 10) in Augusts of the four successive years returned to the northern part of the study area, and the home range was larger only in 1981. For several years in September, groups led by the same marked cow also moved in a similarly located part of the forest. In 1979, the home range was clearly larger than in other years and it also included the central part of the study area. These examples show that in the same seasons of successive years, home ranges overlapped, and the area of the overlap accounted for about $50 \%$ of the searched area. Differences in the size of home ranges in the same seasons were most probably related to the available food supply.

\section{HABITAT PREFERENCE}

\subsection{Utilization of Forest Habitats by Bison}

The area occupied by the mixed groups of bison under study represented a mosaic of forest biotopes. Figure 11 shows a distribution of basic forest types accounting for at least $50 \%$ of forest compartments. This classification takes into account first of all the habitats preferred by bison, and the whole forest compartments are characterized on the basis of the dominance of the following forest types: deciduous forest (DF) (fresh deciduous forest (FDF) and moist mixed deciduous forest (MoMDF) together), mixed coniferous forest (MCF), mixed deciduous forest (MDF), alderwoods (Al) (ash-alderwood (Aa) and alderwood (A)). Other forest types, in which bison were occasionally encountered, or they only moved through these forests, are neglected. Such biotopes not visited by bisons include fresh coniferous forest (FCF), moist mixed coniferous forest (MoMCF), and boggy coniferous forest (BCF). The proportion of these 


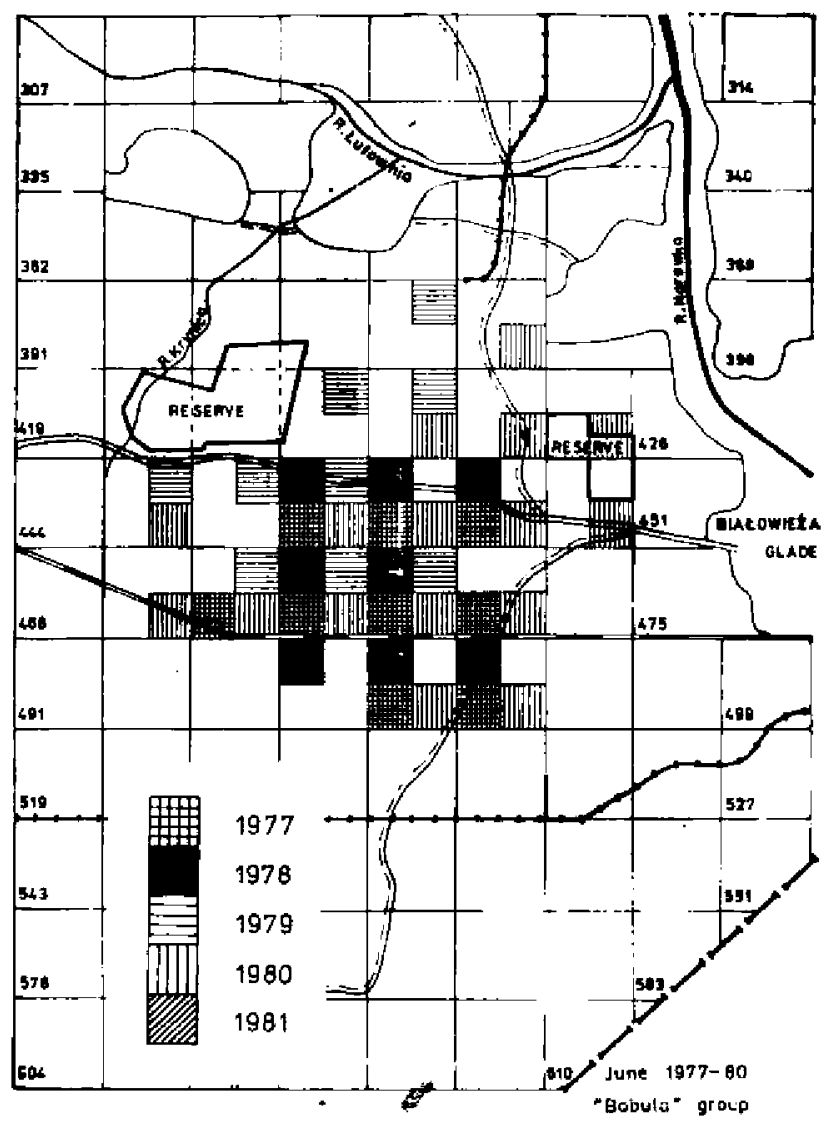




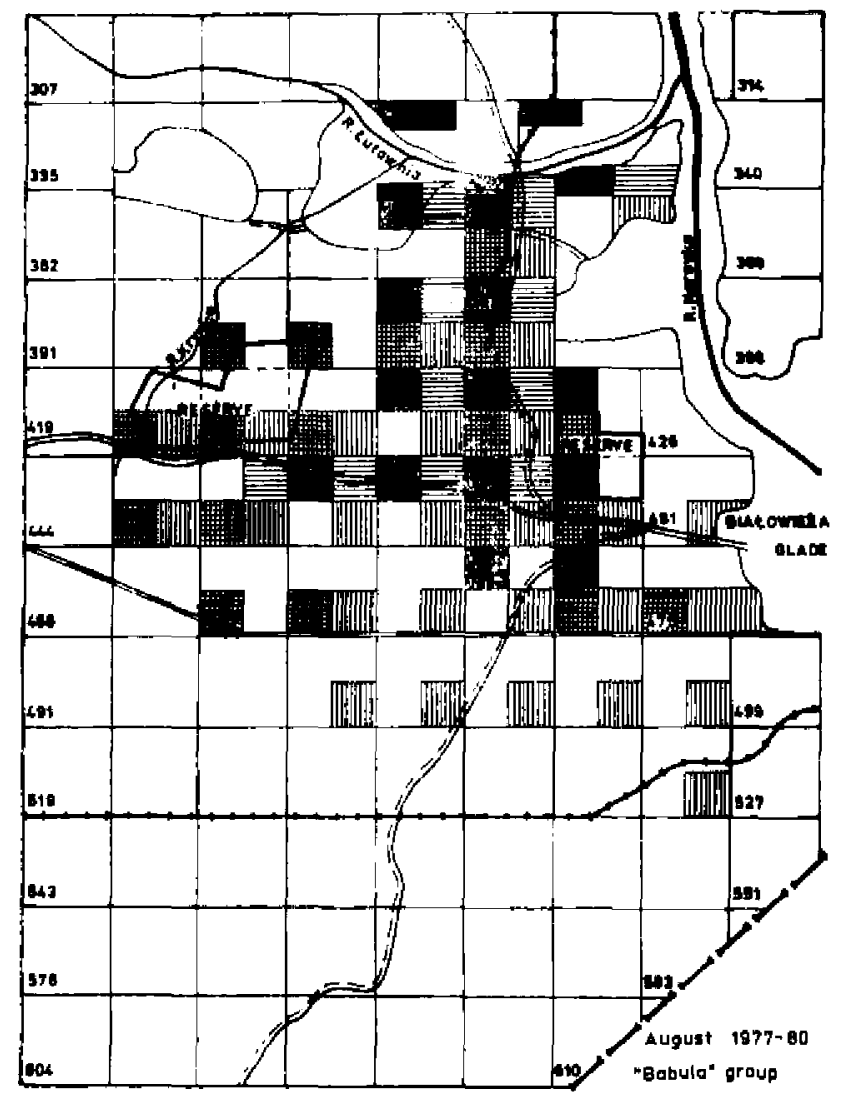

$\stackrel{5}{\oplus}$ 

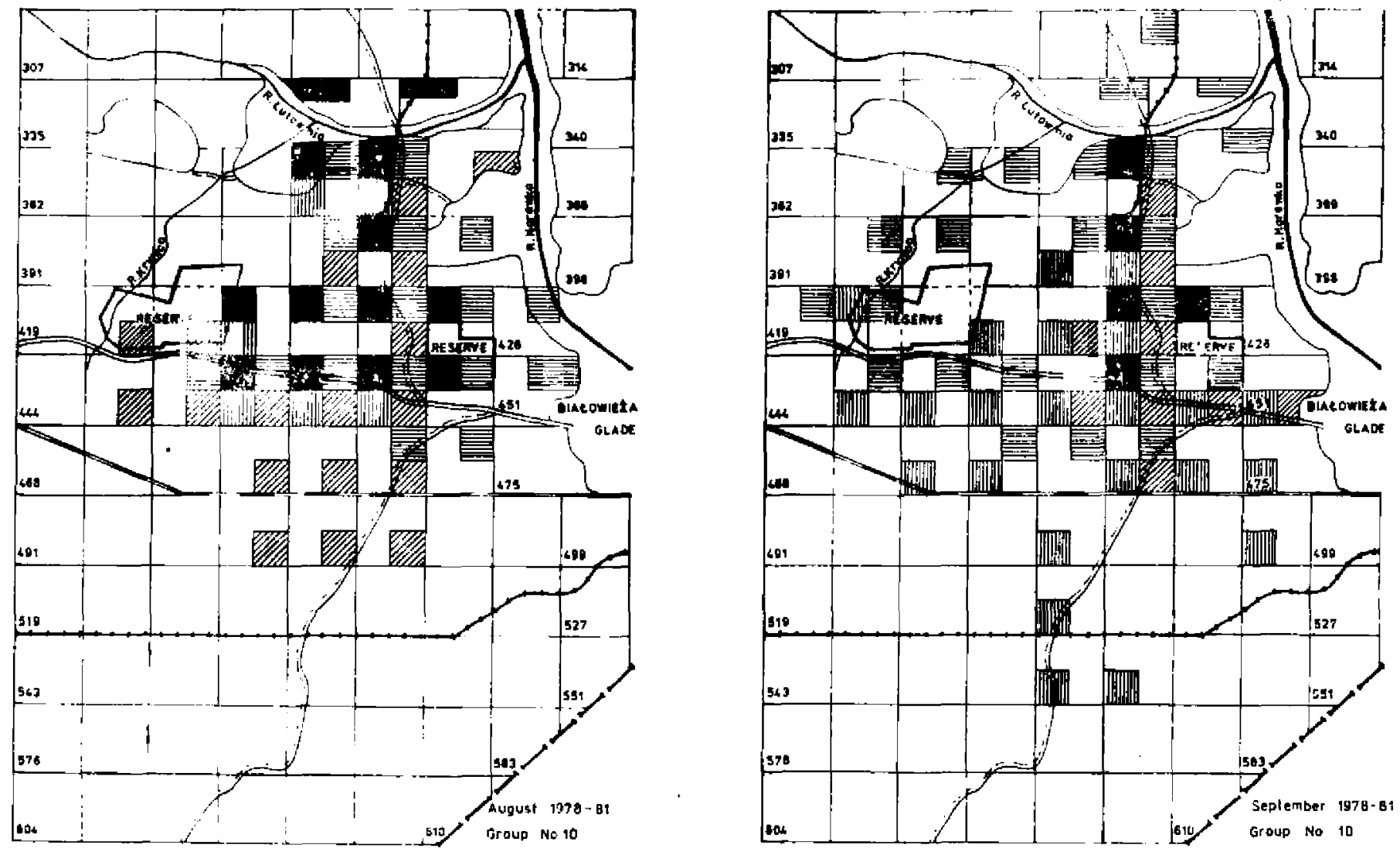

Fig. 10. Spatial distribution of two mixed groups in the same months of four successive years. One-fourth of a square denotes at least one (max. 10) observation of a groups in a given forest compartment in particular months. From the total documentation only the months are selected in which the group identified by the presence of the same leading cow ("Babula" and cow 10) was observed by four successive years. 

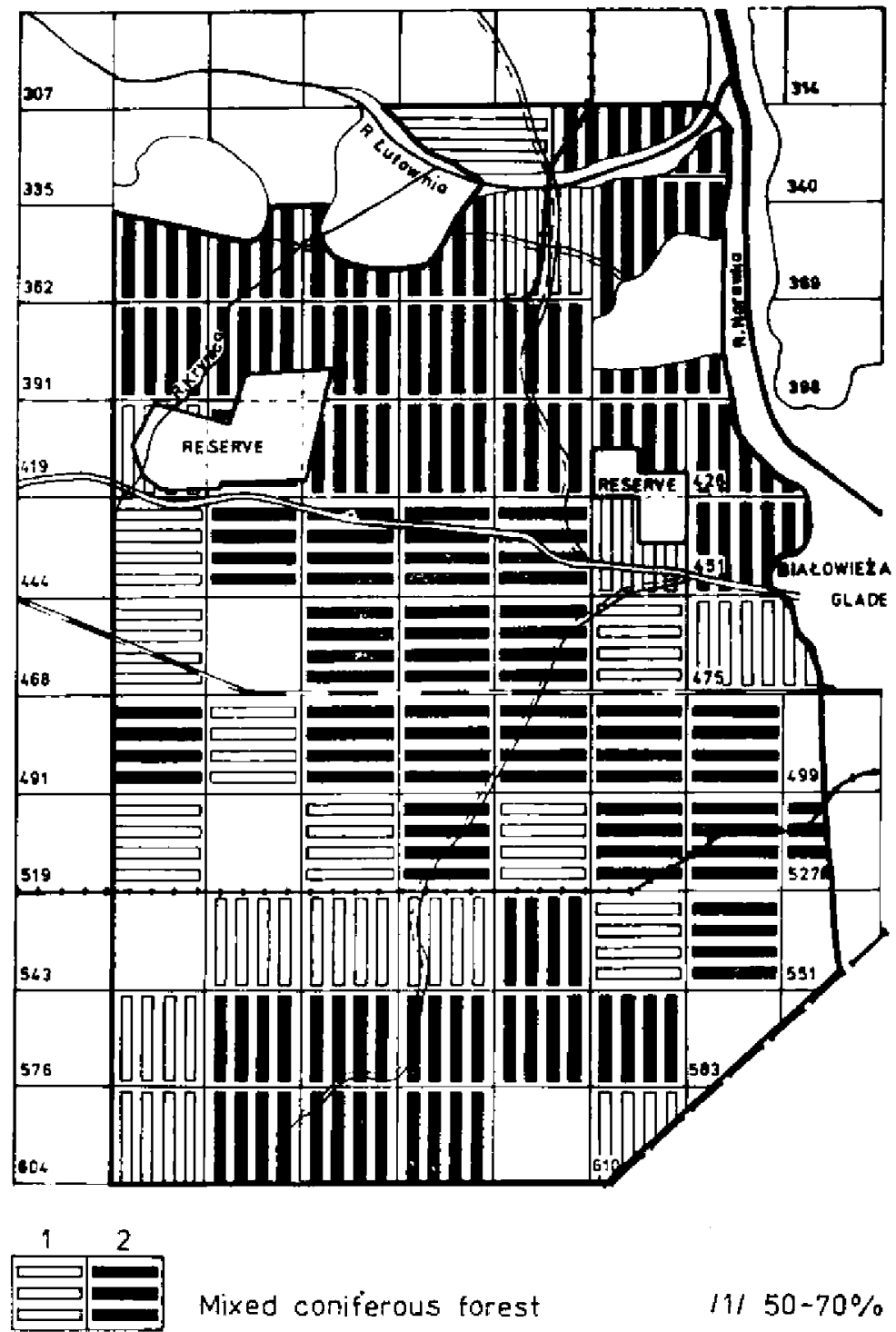

Mixed coniferous forest

$11 / 50-70 \%$

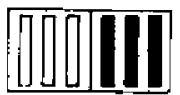

Decidous forests and alderwoods

$121>70 \%$

Fig. 11. Percentage area of forest types in the forest compartments of the Bialowieża Forest under study. Only forest types accounting for more than $50 \%$ of the forest compartment area are shown. Empty spaces denote those forest compartments in which none of forest types occurring occupy 50\% of their area. Fresh and moist deciduous forests also include alderwoods and ash-alderwoods, which only in several compartments occupy more than $50 \%$ of their area. 
biotopes in the study area was small. The most extensive forest types were the mixed coniferous forest and deciduous forest (see Section 2, Material and methods).

Habitat preference in bison was measured by the frequency of observation of mixed groups in particular forest types (Table 4). In all the study years, the frequency of bison observation in FDF was similar. One-third of all observations took place there (31.2-37.2). The fresh deciduous and moist deciduous forests were considered together because of their similarity in terms of the vegetation and the common time of utilization of these forest types by bison. It turned out that DF dominated among the forest habitats utilized by bison. The next forest type with

\section{Table 4}

Frequency of observation ( $\%$ of mixed groups in different forest types of Białowieża Forest. Abbreviations: MCF - Mixed coniferous forest, FDF fresh deciduous forest, MDF - mixed deciduous forest, MoDF - moist deciduous forest, $\mathrm{Aa}$ - ash alderwood, A - alderwood, Me - meadows, FCF - fresh coniferous forest. MoMCF - moist mixed coniferous furest.

\begin{tabular}{lrrrrrrrrrr}
\hline Years & N & MCF & FDF & MDF & MoDF & Aa & A & Me & FCF & NoMCF \\
\hline 1977 & 145 & 40.7 & 37.2 & 8.3 & 5.5 & 3.4 & 2.7 & 0.8 & 0.7 & 0.7 \\
1978 & 244 & 41.4 & 31.6 & 12.3 & 11.1 & 2.0 & 0.8 & - & 0.8 & - \\
1979 & 166 & 33.7 & 31.9 & 14.4 & 15.1 & 3.0 & 0.6 & - & 1.3 & - \\
1980 & 219 & 41.1 & 34.2 & 8.7 & 9.6 & 4.5 & 0.5 & - & 1.4 & - \\
1981 & 249 & 42.6 & 33.3 & 9.6 & 8.0 & 4.5 & 0.8 & - & 1.2 & - \\
1982 & 186 & 40.9 & 31.2 & 16.7 & 5.4 & 3.8 & 1.6 & - & 0.4 & - \\
Avg. & 1209 & 40.4 & 33.0 & 11.6 & 9.2 & 3.6 & 1.0 & 0.1 & 1.0 & 0.1 \\
\hline
\end{tabular}

a similar preference was MCF. The percentage index of the presence of bison in MCF showed little year-to-year variation (33.7-42.6). Both these biotopes (DF and MCF) accounted for more than $80 \%$ of the area utilized by bison. Among the other habitats only the mixed deciduous forest was used in quite a large percentage (8-17). As this forest covered a small proportion of the study area, this indicates that it was highly preferred. The observations of bisons in the other forest types, except in alderwoods, usually did not exceed $1 \%$ of all the observations, so they are of little importance for bison living under natural conditions.

The distribution of bison was closely related to the spatial distribution of the preferred forest types within the home range of a group. The spatial distribution of all observations of bisons in the study period (Fig. 12) was similar to the distribution of DF and MCF (see Fig. 11). As it was expected that the frequency of observation of bisons in different forest compartments reflected their habitat preference, the relationship between the number of group observation and the proportion of forests types in forest compartments was examined (Table 5). It has 
been found that the frequency of observation clearly increased with increasing proportions of two forest types, DF and MCF, which were especially preferred by bison. In the group of forest compartments com-

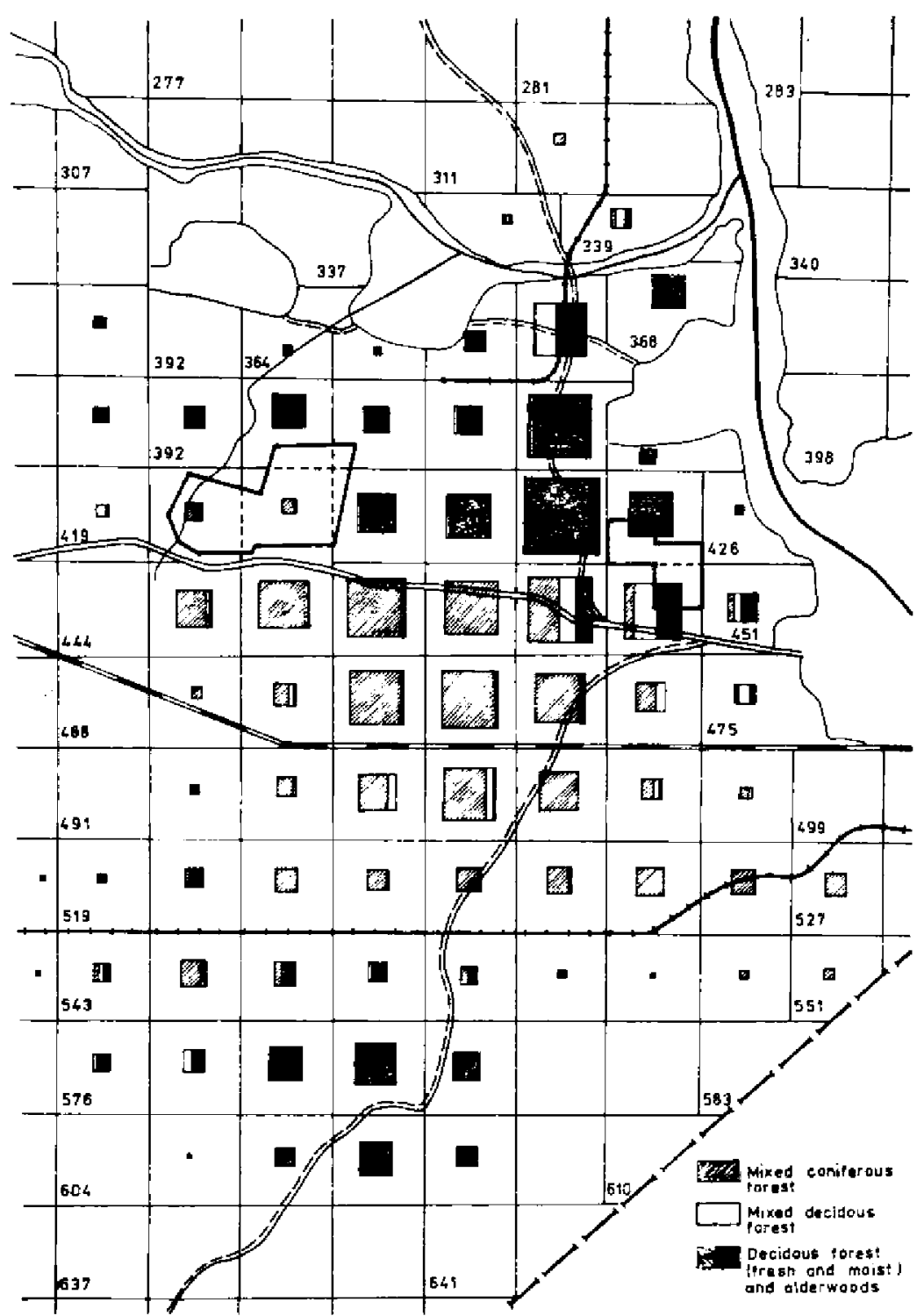

Fig. 12. Frequency of observation of mixed group in forest compartments of the Bialowieża Forest in 1977--1982. The total number of observations of mixed groups was 2052. The sizes of squares are proportional to the mean number of observations per forest compartment in specified forest type. 
Table 5

Relationship between the number of observations of mixed groups of bison (n) in diffenent forest types and the percentage area of these forests in different compartments of the Bialowieza forest.

Frequency of observations of mixed groups per forest compartment in a given forest type

\begin{tabular}{|c|c|c|c|c|c|c|c|c|c|c|c|c|c|c|c|}
\hline \multirow{3}{*}{$\begin{array}{l}\text { Percent } \\
\text { of forest } \\
\text { type area }\end{array}$} & \multicolumn{15}{|c|}{ Frequency of observations of mixed $\mathrm{g}$} \\
\hline & \multicolumn{5}{|c|}{ Mixed coniferous torest } & \multicolumn{5}{|c|}{ Deciduous forest } & \multicolumn{5}{|c|}{ Mixed deciduous forest } \\
\hline & n & $\begin{array}{l}\text { No. } \\
\text { compart- } \\
\text { ments }\end{array}$ & $\overline{\mathbf{x}}$ & SD & $\min -\max$ & $\mathbf{n}$ & $\begin{array}{l}\text { No. } \\
\text { compart- } \\
\text { ments }\end{array}$ & $\overline{\mathfrak{x}}$ & SD & $\min -\max$ & $\mathbf{n}$ & $\begin{array}{c}\text { No. } \\
\text { compart- } \\
\text { ments }\end{array}$ & $\bar{x}$ & $\mathrm{SD}$ & $\min -\max$ \\
\hline $\begin{array}{r}1-25 \\
26-50 \\
51-70 \\
71-100\end{array}$ & $\begin{array}{r}24 \\
67 \\
99 \\
716\end{array}$ & $\begin{array}{r}8 \\
8 \\
9 \\
18\end{array}$ & $\begin{array}{r}3.0 \\
8.4 \\
11.0 \\
38.8\end{array}$ & $\begin{array}{r}5.8 \\
6.1 \\
10.2 \\
32.1\end{array}$ & $\begin{array}{l}0-17 \\
1-15 \\
1-33 \\
1-91\end{array}$ & $\begin{array}{r}57 \\
107 \\
299 \\
396\end{array}$ & $\begin{array}{r}12 \\
9 \\
12 \\
9\end{array}$ & $\begin{array}{r}4.7 \\
11.9 \\
24.9 \\
44.0\end{array}$ & $\begin{array}{r}7.6 \\
10.6 \\
18.0 \\
53.8\end{array}$ & $\begin{array}{l}0-27 \\
4-36 \\
3-53 \\
1-160\end{array}$ & $\begin{array}{r}112 \\
61 \\
0 \\
4\end{array}$ & $\begin{array}{r}25 \\
7 \\
2 \\
1\end{array}$ & $\begin{array}{l}4.5 \\
8.7 \\
4\end{array}$ & $\begin{array}{r}9.1 \\
11.4\end{array}$ & $\begin{array}{l}0-36 \\
1--34\end{array}$ \\
\hline
\end{tabular}


prising more than $70 \% \mathrm{MCF}$, the high frequency of observation in one of them was significantly higher $(0.02<p<0.01)$ than in the other compartments. In the case of DF, a similar trend and high differences in absolute values were observed, but these differences were not statistically significant. This resulted from an uneven searching of compartments with the proportion of DF higher than 70\% (from 1 to 160 observations in one compartment), which accounted for a high $S D$ of the highest mean frequency of observation (Table $5, \bar{x}=44, S D=53.8$ ). The proportion of the mixed deciduous forest was lower in the study compartments. Nonetheless, in some periods of the year they were frequent sites of bison observation, providing an evidence that they may be an important factor determining foraging movements of these animals.

\subsection{Utilization of Stands of Different Ages by European Bison}

The area utilized by the bison herds under study was located in the part of the Białowieża forest exploited for timber for a long time. As a result, forest stands differed in their age, and also clearcuts and young plantations were present.

Table 6

Frequency of the observation of bison in tree stands of different age classes.

Explanations: 1 - clearcuts, young plantations up to $10 \mathrm{yrs}$ and meadows in forests of similar character and with similar food supply, considered together; $2-$ Thickets $10-20$ yrs old; 3 - Pole-size and timber stands.

\begin{tabular}{lccc}
\hline Forest types & 1 & 2 & 3 \\
\hline Fresh deciduous forest & 27.5 & 5.0 & 67.5 \\
Moist deciduous forest & 29.7 & 1.8 & 68.5 \\
Ash alderwood & 14.0 & - & 86.0 \\
Alderwood & 15.4 & - & 84.6 \\
Mixed deciduous forest & 12.9 & 3.5 & 83.6 \\
Mixed coniferous forest & 21.5 & 7.8 & 70.7 \\
\hline
\end{tabular}

Bison showed preference for older age classes. No matter what the forest type was, bison were most frequently observed $(67-86 \%)$ in polesize and timber stands, that is, in forests over 20 years old (Table 6). A high frequency of observation (more than $20 \%$ ) also occurred in clearcuts and young plantations of deciduous and mixed coniferous forests. But in thickets, bison were rarely noted (Table 6). Plantations in DF were most frequently searched in early spring - almost twice as frequently as in summer. In autumn, the frequency of visits to open areas in DF 


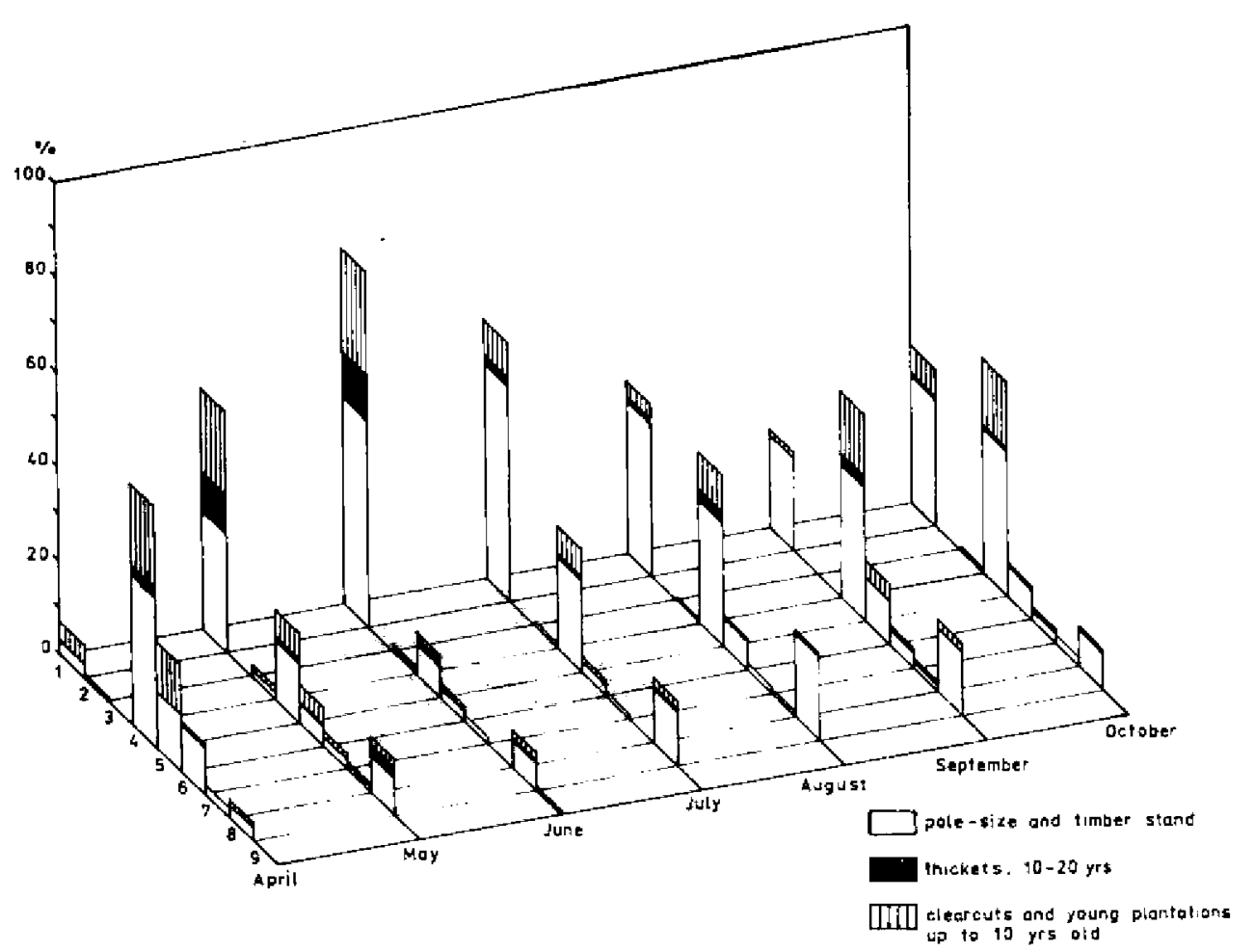

Fig. 13. Seasonal changes in habitat preference by mixed groups of bison in different forest types.

1 - mixed coniferous forest, 2 - moist mixed coniferous forest, 3 - fresh coniferous forest, 4 - fresh deciduous forest, 5 - moist deciduous forest, 6 - ash alderwood, 7 - alderwood, $8-$ mixed deciduous forest, $9-$ meadows in the forest. Three age classes of stand were distinguished: clearcuts and young plantations up to 10 years old, thickets $10-20$ years, and pole-size and timber stands.

increased again (Fig. 13). Plantations in MCF were most frequently visited from spring to June. The visits to more than 20-year-old parts of DF increased from July to October, while in the case of MCF they were most frequent from May to July (Fig. 13). Also the type of the forest in the phases of clearcuts or young plantations reveals the habitat preference of bison. More than half of the observations of mixed groups was in DF and the second position (ca. 40\%) was occupied by MCF (Fig. 14).

No relationship was found between the frequency of observation in forest compartments and the proportion of surface area occupied by clearcuts and young plantations up to ten years old (Table 7). But several compartments most preferred by bison $(424,396,471$, and 472 ; Fig. 12) 
Table 7

Frequency of visits to different compartments of the Bialowieża Forest by mixed groups of bison in relation to the proportion of young plantations in these compartments.

\begin{tabular}{|c|c|c|c|c|c|}
\hline \multirow{2}{*}{$\begin{array}{l}\text { Percent of } \\
\text { plantations } \\
\text { up to } 10 \mathrm{yrs} \text {. }\end{array}$} & \multirow{2}{*}{$\begin{array}{l}\text { No. } \\
\text { compart- } \\
\text { ments }\end{array}$} & \multirow{2}{*}{$\begin{array}{c}\text { Percent } \\
\text { of all } \\
\text { observations }\end{array}$} & \multicolumn{3}{|c|}{$\begin{array}{l}\text { Number of observations per } \\
\text { compartment }\end{array}$} \\
\hline & & & Avg. & SD & $\min -\max$ \\
\hline 0 & 15 & 19.7 & 26.5 & 43.7 & $1-115$ \\
\hline $0.1-3.0$ & 17 & 18.9 & 22.5 & 22.6 & $1-78$ \\
\hline $3.1-6.0$ & 6 & 4.5 & 15.0 & 14.8 & $3-47$ \\
\hline $6.1-9.0$ & 8 & 8.8 & 22.2 & 16.6 & $3-55$ \\
\hline $9.1-12.0$ & 5 & 14.0 & 56.4 & 32.4 & $1-77$ \\
\hline $12.1-15.0$ & 7 & 5.2 & 14.9 & 9.1 & $3-31$ \\
\hline $15.1-33.4$ & 14 & 28.9 & 41.7 & 47,2 & $5-161$ \\
\hline
\end{tabular}

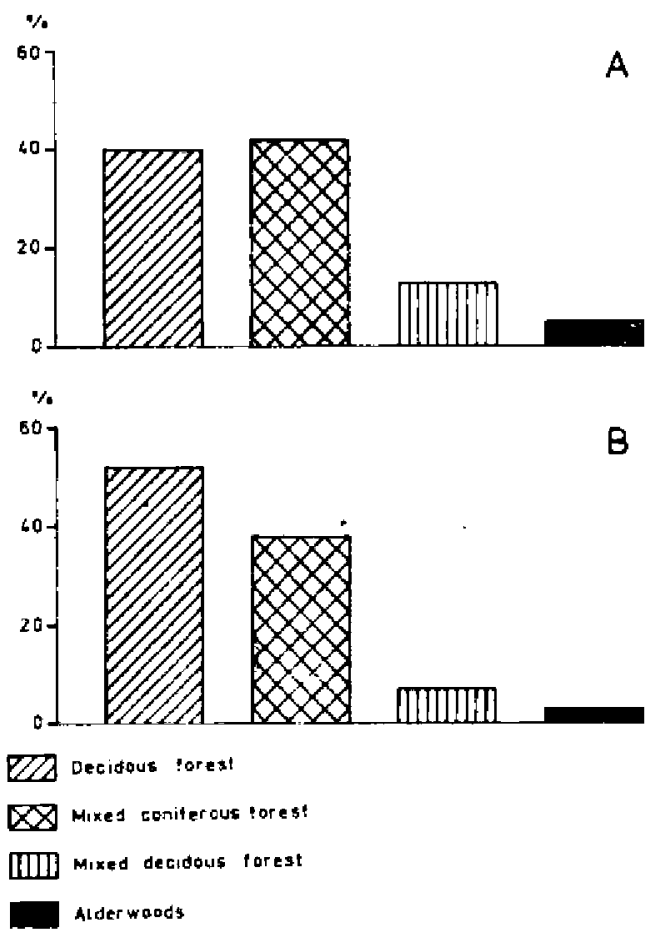

Fig. 14. Frequency of observation of mixed groups of bison in different forest types in areas covered with stands older than 10 years (A) and in an open area comprising meadows, clearcuts and plantations up to 10 years old (B).

$72 \%$ observations took place in pole-size and timber stands, $5 \%$ in thickets, and $23 \%$ in open area (meadows, clearcuts and plantations up to $10 \mathrm{yrs}$. old). 
had a high percentage of young plantations, which is not seen when the mean frequency of visits is considered. This class of forest habitats is thot attractive to bison in summer. The frequency of observation of bison in these habitats presumably depends on the configuration of clearings and timber stands in the preferred forest habitats.

\subsection{Seasonal Changes in the Utilization of Biotopes}

The utilization of different forest types by bison changed from season to season (Figs. 15 and 16). Based on several-year observations, three periods differing in the frequency of visits to different forest types by bison were distinguished: 1) spring period, covering April and May, 2) summer period, in June and July, and 3) autumn period, covering the second half of summer (August and September) and autumn through October.

Since the time of snow melting, usually in the second half of April, bison left the places where they were permanently supplied with food and they started living on natural food, first on bark and browse, and at the end of April also on the herb-layer vegetation, with hay in addition at the beginning. The most preferred food in this period is bark and browse of cut down aspens (Populus tremula). Bison clearly prefer DF (Fig. 16). In early spring, they still most frequently visited forest compartment 424 , characterized by the highest proportion of FDF in the study area. In May, bison evenly dispersed over their range (Fig. 15.1). At that time they visited the highest number of different forest types, that is, 7 (Table 8 ), this being related to a small food supply at that time of the year and to differences in the onset of vegetation growth in different habitats. In spring, mixed groups were dispersed, foraged in areas located far apart (Fig. 7), and they rarely joined each other (23.2\% of all cases). Firstly they were feeding in DF (51.3\%), Iater also in $\mathrm{MCF}\left(41.8^{\mathrm{n}}\right)$.

In the summer period, bison mostly stayed in MCF (71.1\%). The frequency of visits to DF declined $(22.5 \%)$. MDF was rarely visited, like in spring (Fig. 16). Groups of bison were concentrated on smaller areas (Fig. 15.2), and they repeatedly searched the same territories (Fig. 7), and the groups frequently merged $(32.6 \%)$.

Starting from August until autumn, visits to DF increased again $(58 \%)$, also to MDF ( $15 \%$, whereas the number of visits to MCF decreased (Figs. 15, 16). In August and September, groups were concentrated in the northern part of the study area. Their home ranges frequently overlapped there (Fig. 7) and groups often merged (44.2\%). 


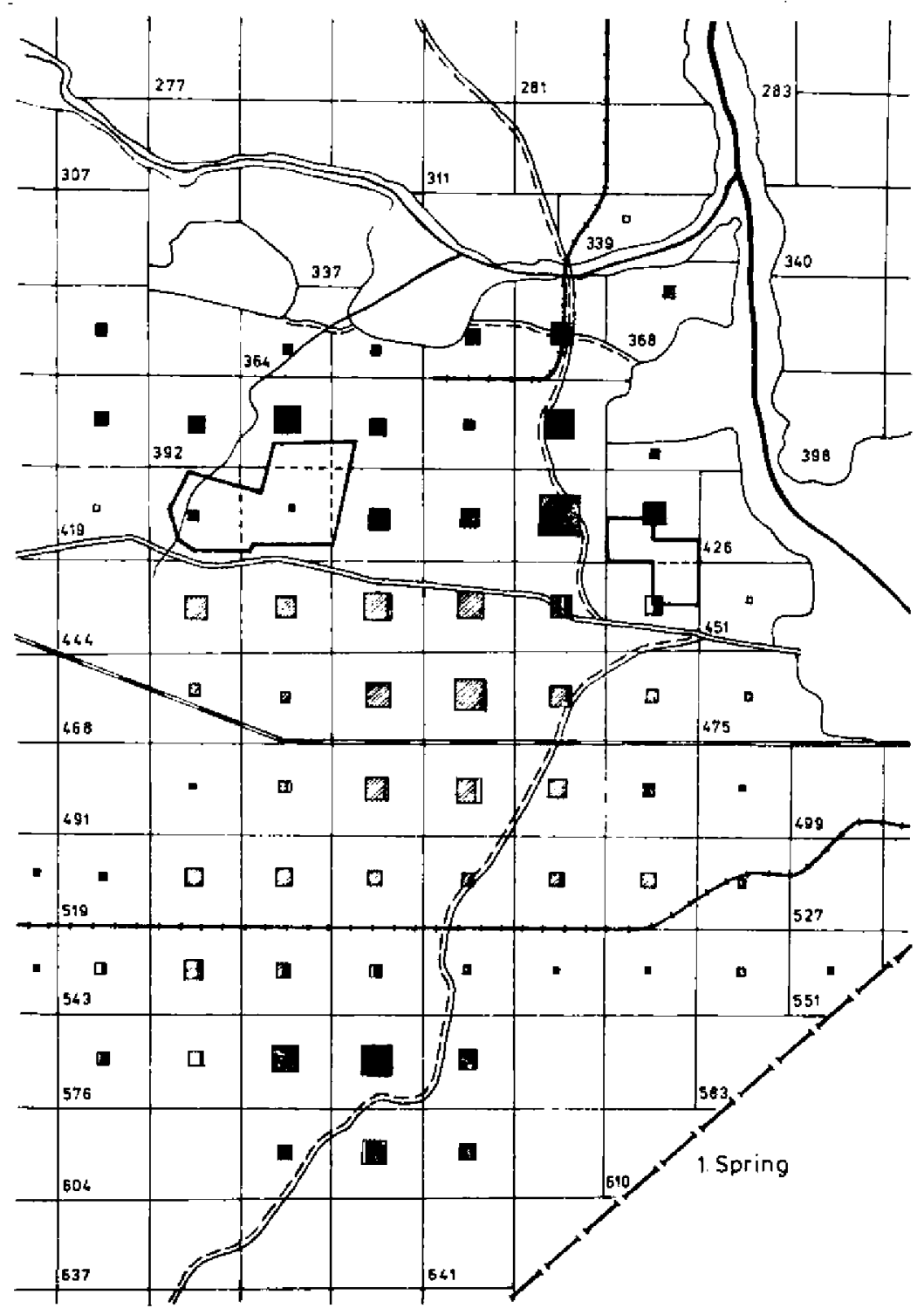

Fig. 15.1. (For explanation see p. 186). 


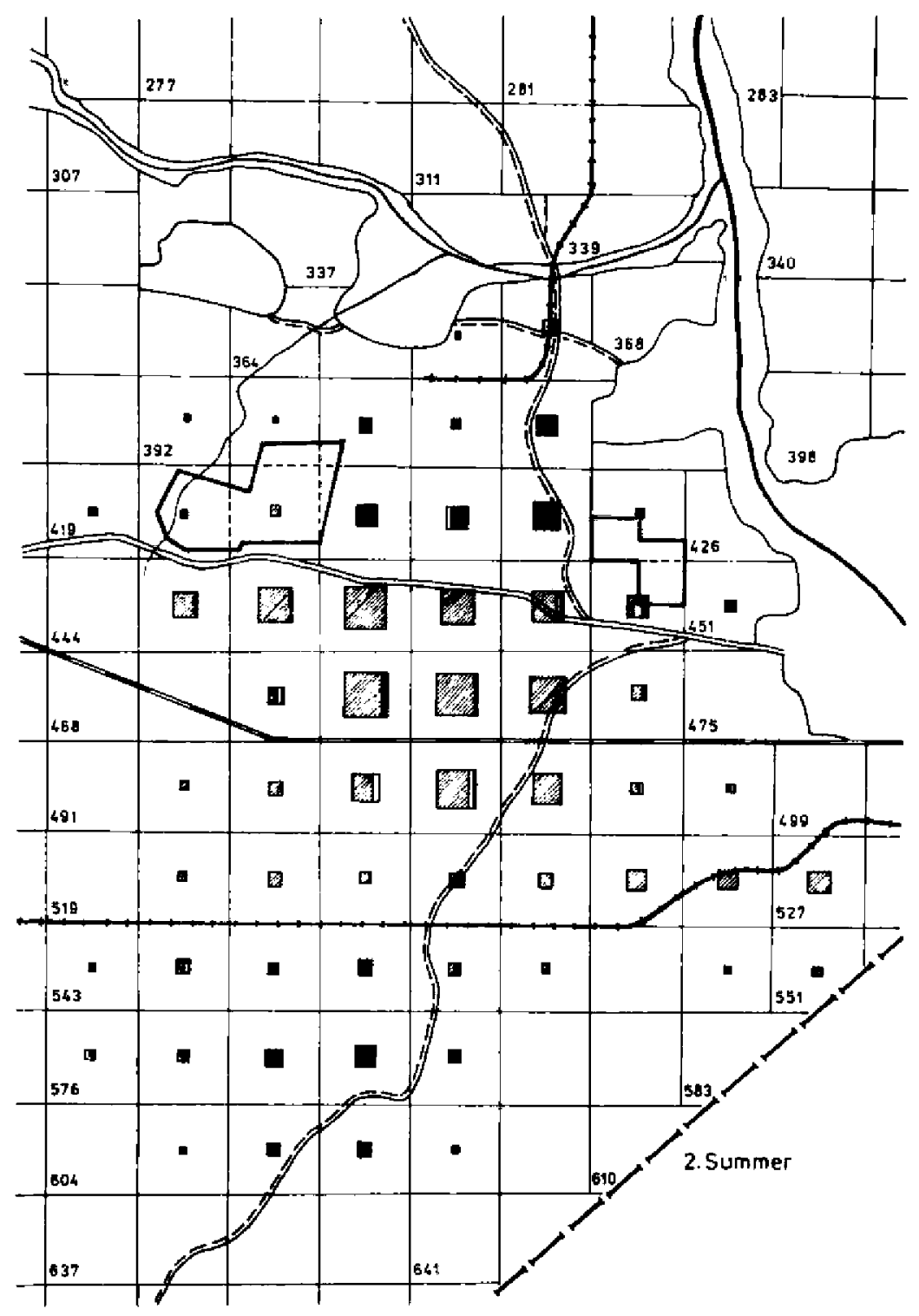

Fig. 15.2. 


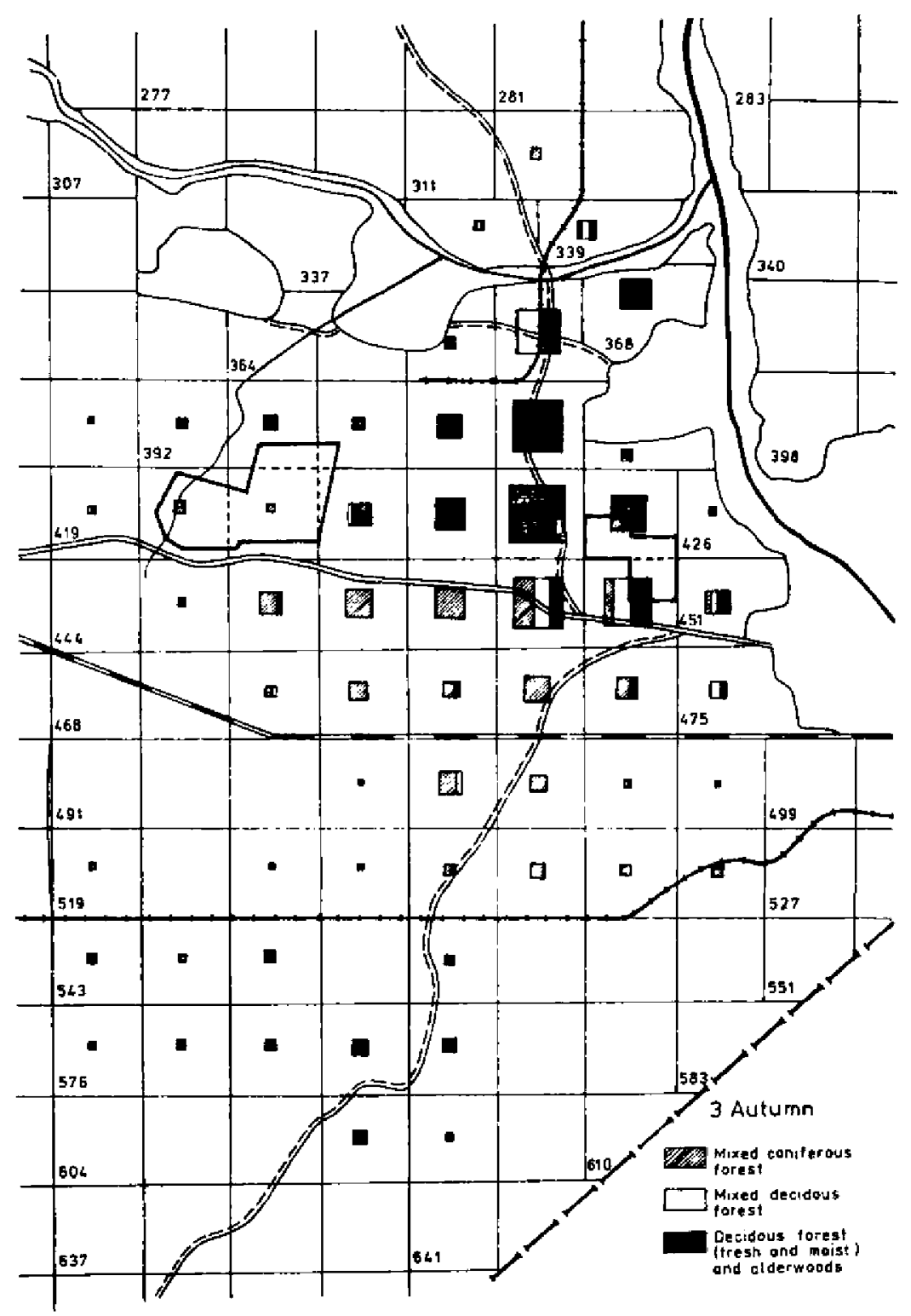

FIg. 15.3.

Fig. 15. Seasonal changes in habitat preference, as expressed by the frequency of observation of mixed groups of bison in forest compartments.

Spring - (April - May), Summer - (June - July), Autumn - (August - October). The sizes of squares are proportional to the number of observations of mixed groups in a given forest type and compartment. 
The most balanced utilization of the three forest types (DF, MCF, MDF) occurred in mid-summer (July, August). The other biotopes, except for alderwoods, did not play an importaint role in the foraging of bison (Fig. 16).

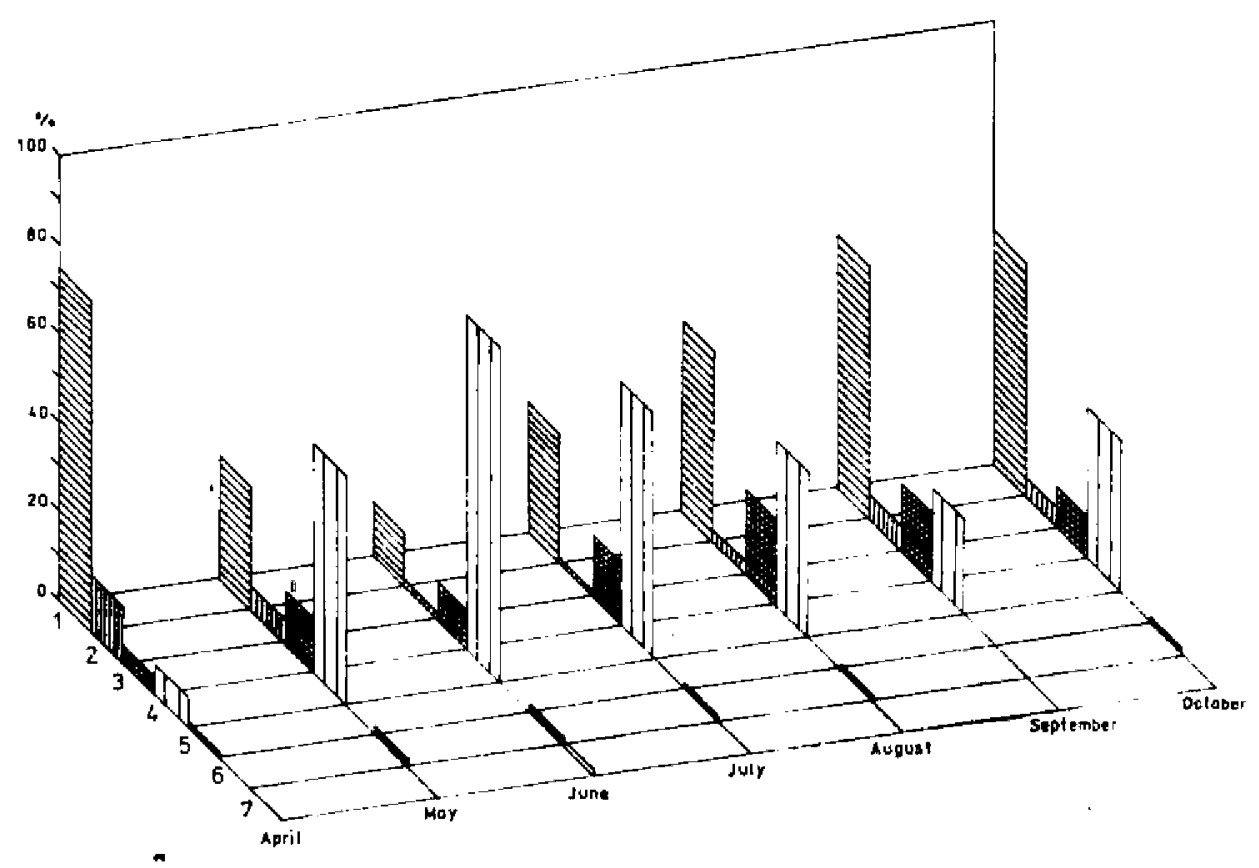

Fig. 16. Seasonal changes in habitat preference of mixed groups of bison in the Bialowieża Forest.

(1) - deciduous forest (fresh and moist), (2) - alderwoods, (3) - mixed deciduous forest, (4) - mixed coniferous forest, (5) - fresh coniferous forest, (6) - moist mixed coniferous forest, (7) - meadows.

\subsection{Annual Variation in the Utllization of the Habitat}

In addition to seasonal changes in the utilization of the forest, also year-to-year changes in the intensity of this process were observed. The home range size of bison groups showed especially large differences for the years largely differing in weather conditions. The weather was wet in 1978, enhancing the growth of vegetation, whereas 1979 was dry for most of the growing season, accounting for a decline in food supply, mostly grasses and forbs, in different forest types. In June 1978, with frequent rainfalls at an average air temperature of $15.8^{\circ} \mathrm{C}$, and insolation of $7.3 \mathrm{~h}$, the group "Pocieszna" remained within a small home range, foraging mostly in MCF and MDF. But in June 1979, the year in which 
Table 8

Habitat preference in mixed groups of bison in the seasons without snow cover in different years, expressed as percentage frequency of observations. For explanations see Table 4.

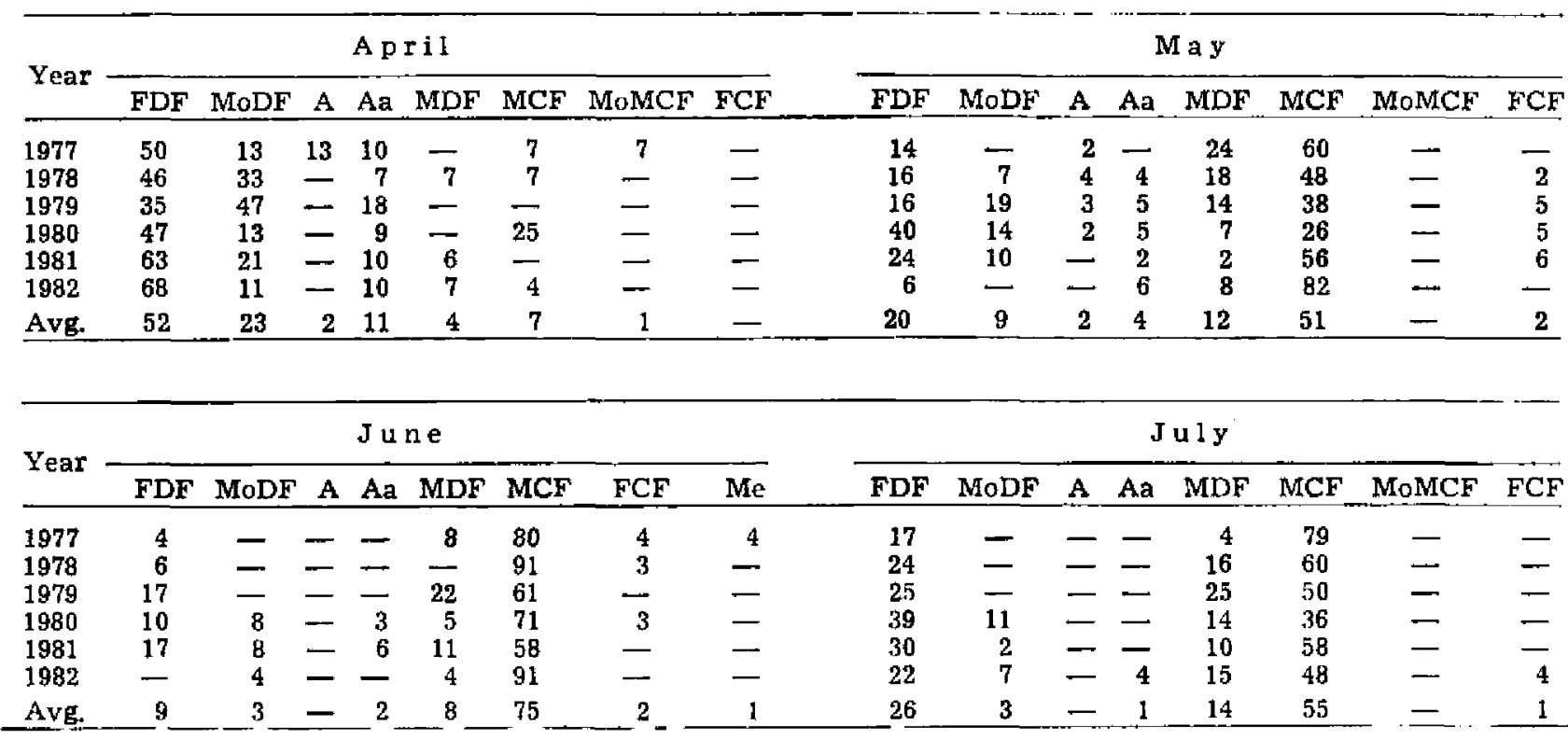




\begin{tabular}{|c|c|c|c|c|c|c|c|c|c|c|c|c|c|c|c|c|c|c|}
\hline \multirow{2}{*}{ Year } & \multicolumn{9}{|c|}{ A ug ust } & \multicolumn{9}{|c|}{ September } \\
\hline & FDF & MoDF & $\mathbf{A}$ & $\mathrm{Aa}$ & MDF & MCF & MoMCF & $\mathrm{FC}$ & & & FDF & MoDF & A & Aa & MDF & MCF & MoMCF & FCF \\
\hline $\begin{array}{l}1977 \\
1978 \\
1979 \\
1980 \\
1981 \\
1982\end{array}$ & $\begin{array}{l}56 \\
45 \\
40 \\
21 \\
32 \\
24\end{array}$ & $\begin{array}{r}-3 \\
20 \\
5 \\
10\end{array}$ & $\frac{\bar{Z}}{\overline{2}}$ & $\frac{\overline{3}}{\frac{5}{5}}$ & $\begin{array}{r}19 \\
23 \\
13 \\
8 \\
15 \\
33\end{array}$ & $\begin{array}{l}25 \\
26 \\
27 \\
71 \\
38 \\
33\end{array}$ & $\begin{array}{l}\bar{Z} \\
\bar{z}\end{array}$ & $\bar{I}$ & $\frac{-}{2}$ & & $\begin{array}{l}35 \\
69 \\
44 \\
37 \\
39 \\
42\end{array}$ & $\begin{array}{r}24 \\
17 \\
20 \\
5 \\
8 \\
4\end{array}$ & $\begin{array}{l}\bar{Z} \\
\overline{8}\end{array}$ & $\frac{12}{\frac{10}{4}}$ & $\begin{array}{l}\overline{14} \\
20 \\
14 \\
12 \\
34\end{array}$ & $\begin{array}{r}29 \\
16 \\
34 \\
41 \\
8\end{array}$ & $\begin{array}{l}I \\
\bar{I} \\
\bar{I}\end{array}$ & $\begin{array}{l}= \\
\bar{z} \\
\bar{z}\end{array}$ \\
\hline \multirow[t]{5}{*}{ Avg. } & 36 & 6 & 1 & 1 & 18 & 37 & - & & 1 & & 45 & 13 & 1 & 4 & 16 & 21 & - & - \\
\hline & & & & & \multicolumn{10}{|c|}{ October } & & & & \\
\hline & & & & & - & FDF & MoDF & $\mathrm{A}$ & Aa & MDF & $\mathrm{MCF}$ & F MoMC & $\mathrm{CF}$ & FCF & & & & \\
\hline & & & & & $\begin{array}{l}1977 \\
1978 \\
1979 \\
1980 \\
1981 \\
1982\end{array}$ & $\begin{array}{l}82 \\
16 \\
46 \\
46 \\
28 \\
57\end{array}$ & $\begin{array}{r}4 \\
18 \\
17 \\
3 \\
-\end{array}$ & $\frac{4}{-}$ & $\begin{array}{r}\frac{4}{E} \\
4 \\
7 \\
-\end{array}$ & $\begin{array}{r}4 \\
9 \\
4 \\
8 \\
11 \\
17\end{array}$ & $\begin{array}{r}4 \\
57 \\
46 \\
25 \\
48 \\
22\end{array}$ & $\begin{array}{l}- \\
z \\
-\end{array}$ & & $\begin{array}{l}\bar{z} \\
= \\
=\end{array}$ & & & & \\
\hline & & & & & Avg. & 46 & 7 & 2 & 2 & 9 & 33 & - & & 1 & & & & \\
\hline
\end{tabular}



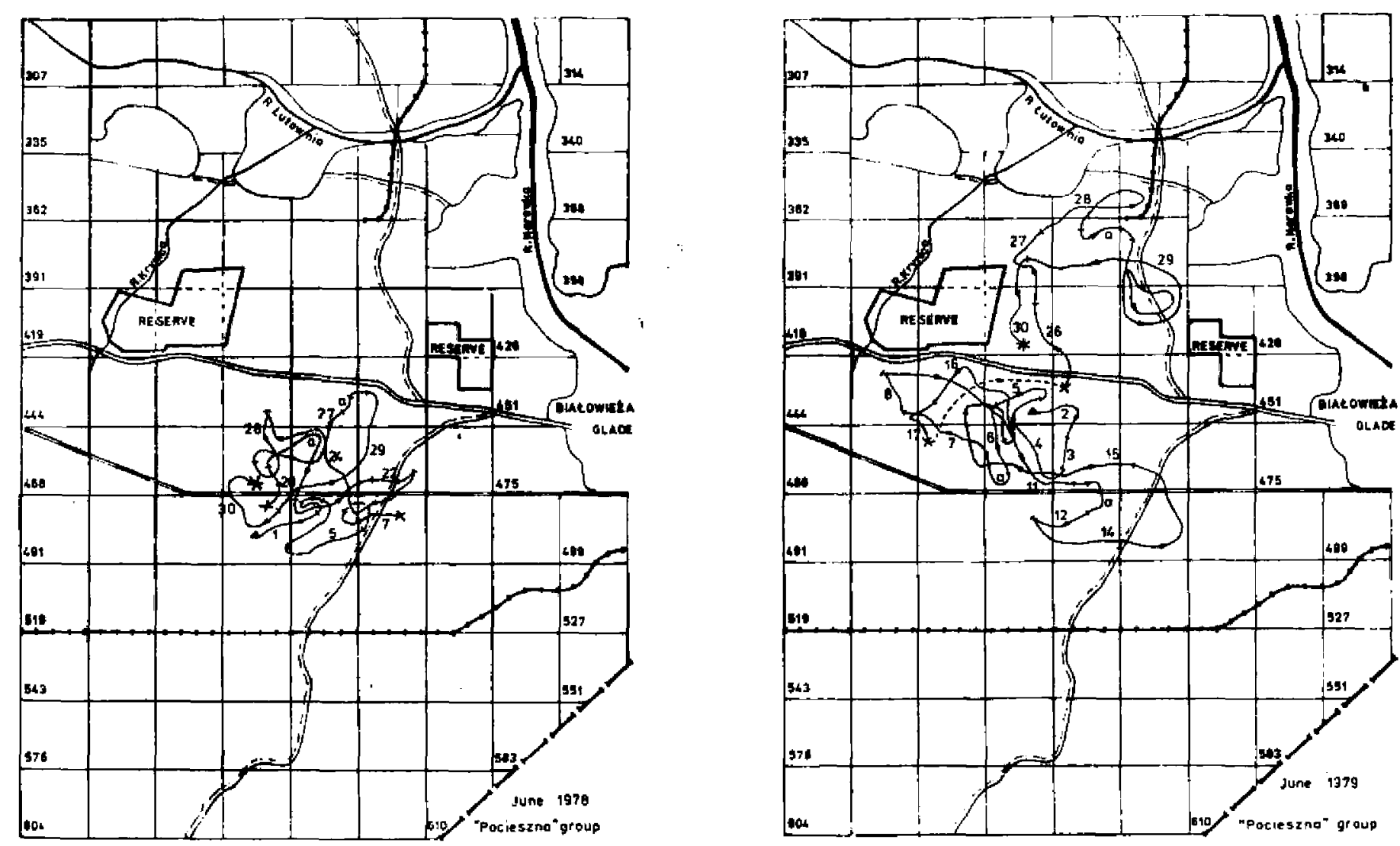

Fig. 17. Route of movements of the group "Pocieszna" in the same season of two different years. For explanations see Fig. 8. 
hot and dry weather extended from May to the end of June (mean air temperature of $20^{\circ} \mathrm{C}$, mean insolation $10.5 \mathrm{~h}$ ), the group led by the same cow as in the preceding year firstly stayed in the same areas but then moved to an area dominated by DF, largely increasing its home range (Fig. 17). Similar differences occurred in September of these two years. In September of 1978, group "Babula" generally occupied four forest compartments during rainy weather, whereas in 1979 it was on a long move, extending many times its preceding-year home range (see Figs. 9.2 and 18). In September of 1979 , the sum of precipitation was lower at a higher air temperature and insolation, as compared with September of 1978. The seasonal differences in habitat preference by bison in successive study years are illustrated in Table 8. For example, in June typically the mixed coniferous forest is preferred (about $80-90 \%$ of all observations), but in the dry season of 1979 , this habitat was utilized only in about $60 \%$, and in 1981, which was also dry, in $58 \%$. At the same time, the utilization of MDF and DF increased. In the wet Septemper of 1979, no bison visited MCF; they foraged in DF and MDF, where the same pastures were utilized on alternate occasions.

Most of the seasonal differences in home range size, rate of habitat utilization, and habitat preference we related to the effect of climatic conditions in any given year, or part of the growing season, on vegetation of the herb layer, the basic component of the diet of bison. Food deficiency or reduced food quality, for example, as a result of grass aging or poor regeneration during drought, lead to changes in movements of bison in the forest habitats, changes in home ranges of groups and in the total foraging activity of bison. Food conditions in the forest have a complex effect on the habitat utilization by bison. This is reflected by both the intensity of penetration and the habitat preference, and determines the way of utilization of this forest complex as a whole.

\section{DISCUSSION}

\subsection{Variation in the Size and Composition of Mixed Groups}

The early literature suggested that family groups formed the core of the group structure of European bison populations (Karcov, 1903; Wróblewski, 1927). The same was suggested for the American bison (Soper, 1941; McHugh, 1958). Krasinski (1978) has shown that the size and composition of the European bison mixed groups can vary. Also the groups formed in the first years of the free bison breeding in the Białowieza Forest were not stable, although they consisted of the animals originating from enclosure reserves (Scibor, 1959; Krasiński, 1983). Recently, also 


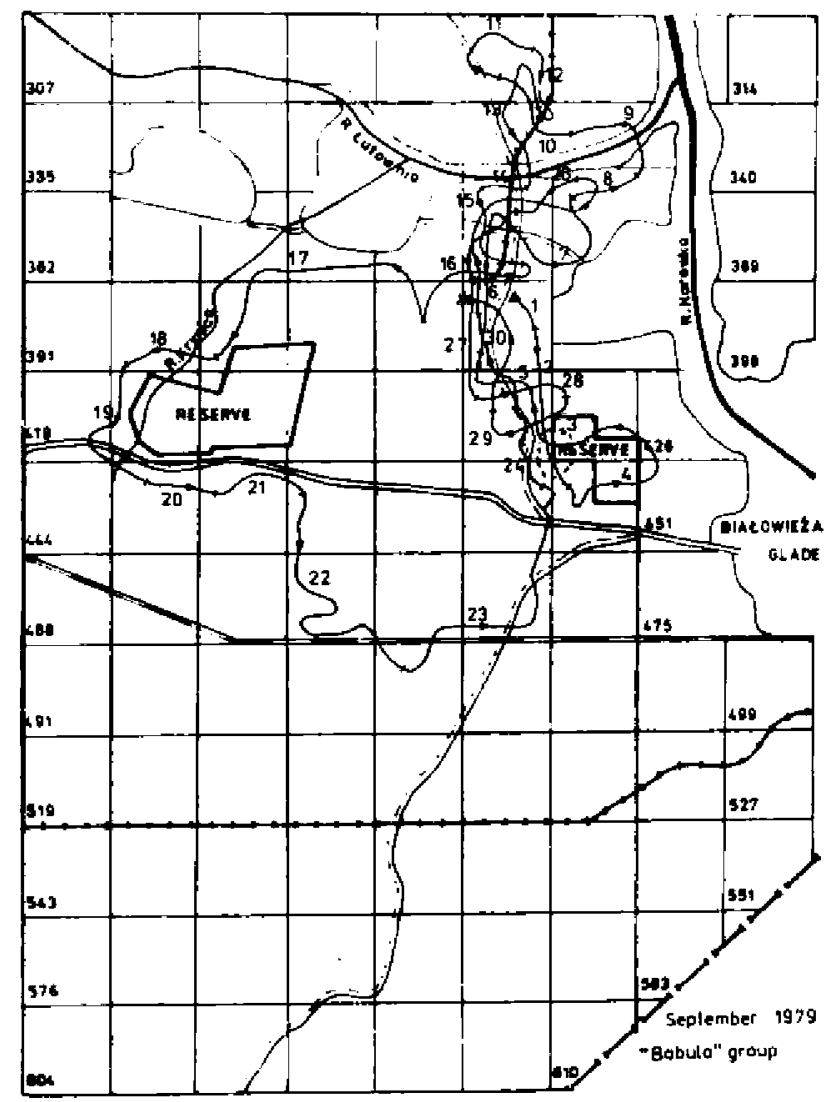

Fig. 18. Route of movements of the group "Babula" in September of 1979. For explanations see Fig. 8.

Lott and Minta (1983), who observed marked American bison in a population living on the Santa Catalina Island, have found that the composition of mixed groups is partly random, and persistent associations concern only temporal mother-calf relationships. Also Van Vuren (1983), who observed the American bison population in the Henry Mountains, has found that the social structure is flexible, group composition changes frequently, typically during encounters of different groups. He has found no evidence for the occurrence of clans or basic units in the social structure of the American bison. Except for cow-calf and cow-yearling pairs, no association among bison existed longer than 21 days.

The present study of mixed groups, identified by the presence of marked individuals, confirmed the earlier observations of variation in the composition of these groups. In successive years, the same leading cow attracted different individuals, with only a low proportion of the 
same individuals, mostly cows. Changes in groups occur during the formation of a group in early spring and also throughout the growing season. These changes depend on behavioural factors (rut, calving) and on other factors (occupying common areas and frequent encounters of groups, exchange of individuals between groups). It turned out that the most persistent element of the group were adult cows, and the most labile element were adult bulls. The latter fact is important to the population $\therefore$ as it ensures a free flow of genes.

The result of the present study suggest, that in the period without snow cover the social structure of the bison population is still based on some relationships existing in the two large winter aggregations (390 and 422 compartments (Fig. 1). All the marked bison originate from one winter aggregation (422). Over the six-year study period only young marked bulls remained for longer periods in the second winter aggregation (390) (10 different individuals in successive years), and on one occasion a marked cow 11 was recorded there.

In early spring, large aggregations split into smaller mixed groups dispersing throughout the forest. At that time the groups originating from different winter aggregations maintain separate home ranges, overlapping only in the central part of study area (Fig. 1). In our view, in the period from spring to autumn, individuals originating from the two winter aggregations rarely exchange themselves. Over the six-year study period, this happened only ten times, when marked cows temporarily stayed beyond their basic summer home range. Young marked bulls, however, were observed, although rarely, on the areas occupied by bison from the other winter aggregation, but they were in both mixed groups and bull groups. These facts show that the formation of winter aggregations is an important factor influencing the stability of the spatial structure of mixed groups of bison. This is also indicated by the occurrence of distinct aggregation in the Polish and Russian parts of the forest. It seems, however, that relatedness has an effect on the development of winter aggregations. For example, two related cows, Babula and 10 , occurred in the same winter aggregation in successive years. Also the offspring of the cow Pocieszna, which were easy to identify because of their light horn tips, occurred at the same feeding site. On the other hand, the winter aggregation under study was formed gradually with increasing number of individuals in the population, and in the place which during the first years (1958-1963) was occupied by winter aggregations of bulls (Krasinski, 1978).

Like the composition, also the size of mixed groups varied in the period from spring to autumn. The mean annual size of a mixed group was 17.4 individuals. Krasinski (1978), who studied earlier the whole 
Białowieża population, recorded a lower mean group size of 12.0 individuals, with $90 \%$ of observations of groups smaller than 20 individuals. Shackleton (1968) observed similar group sizes of the American bison living in forests of the Elk Island National Park. The mean group size of the American bison on the Santa Catalina Island was also small (13 individuals) and clearly increased in the rutting season (Lott \& Minta, 1983), like in Białowieża. In the present study, large groups were rarely encountered (11\% of the observations), and they were formed as a result of junction of two or more small mixed groups. A group up to 20 individuals probably represents an optimum size in the case of both European and American bison living in forests. From the point of view of the utilization of resources, a small group of large herbivorous animals should cause smaller changes as a result of foraging. Due to this the rotative use of pastures within home ranges of the groups is facilitated. Variation in the composition and size of groups was also observed in other ungulates, for example, in the red deer (Dzięciolowski, in litt.). Also in roe deer herds, like in bison, there exist a permanent set of individuals attracting other individuals (Bresinski, 1983).

\subsection{Home Ranges of Mixed Groups}

The study carried out by Krasinski (1978) implies that until 1973, the European bison population had not occupied the whole area of the Polish part of the Biatowieża Forest in the period without snow cover. In the following years, the area occupied by bison did not markedly change, being 13,200 ha (Fig. 1). Only adult bulls (single or in small groups) dispersed beyond the basic area utilized by mixed groups and bulls. Some of them reached remote parts of the forest and they were not in touch with the rest of the population for long periods (Krasinski, 1978). A single mixed groups occupies an area of about 5,000 ha, and all groups originating from the winter aggregation in forest compartment 422 remain within an area of 6,480 ha. Mixed groups of the European bison are not territorial, unlike groups of the water bufallo Bubalus bubaius (Tulloch, 1978). Also herds of American bison have no permanent territories (Lott \& Minta, 1983). These authors determined home ranges of three adult cows frcm the American bison population on the Santa Catalina Island. They were $69.3,58.6$ and $39.0 \mathrm{~km}^{2}$. Similarly, the summer home range of cows from the American bison population in the Heary Mountains was $52 \mathrm{~km}^{2}$, on the average (Van Vuren, 1983). Presumably, these values correspond also to home ranges of groups. These data are higher than for the European bison in the Białowieża Forest, where the largest home range of a mixed group recorded in May of 
1978 was $38.6 \mathrm{~km}^{2}$, and the lowest home ranges, recorded in April and September, were only $5.7 \mathrm{~km}^{2}$. The mean home range of a mixed group over the season was $47 \mathrm{~km}^{2}$. It is possible that larger home ranges of American bison are related to seasonal migrations of these animals. In the large population of the American bison living in the Wood Buffalo National Park, seasonal migrations of animals were related to their movement to qualitatively different refuges (Tempany \& Cooper, 1976). In the Białowieża forest, the European bison do not show tendencies to seasonal migrations, and the movements of groups can be characterized as foraging movements over the mosaic of forest habitats. The size and distribution of home ranges of mixed groups of bison in the Białowieża Forest vary from season to season and they depend on the available food supply. In corresponding seasons of different years, the location of home ranges may be similar, whereas their sizes may vary depending on weather conditions, which, in turn, determine plant cover.

\subsection{Food Preference and the Pattern of Habitat Utilization}

European bison, like most large ruminants, are not highly selective in their diet. Using the Jarman (1974) classification of foraging types, they can be included to types $D$ or $E$, characteristic of the wildebeest, Cannochaetes taurinus (Burchell, 1923), buffalo, Syncerus caffer Sparmann, 1777, or eland, Taurotragus oryx (Pallas, 1766). These two types of feeding are similar to those proposed for wild ruminants by Hofmann (1978), who distinguished grassfeeders living on grass and fibre (Gras-Rauhfutterfresser), which are represented by mouflons, Ovis musimon (Pallas, 1766), sheep, Ovis aries Linnaeus, 1758, cattle, Bos taurus dom. Linnaeus, 1758, and, to a lower extent, European and American bison, wildebeest and buffalo, and animal living on a mixed diet, which are represented by red deer, Cervus elaphus Linnaeus, 1758, fallow deer, Dama dama (Linnaeus, 1758) and in part, chamois, Rupicapra rupicapra (Linnaeus, 1758). In these types of feeding, sites where most of the preferred plants of the herb layer densely cover large patches are selected rather than individual plant species of their edible parts. In this way, energy requirements of an organism can be met relatively fast. Even in roe deer, Capreolus capreolus (Linnaeus, 1758), which is considered a highly selective herbivore (Hofmann, 1978), diet is flexible, depending on the actual food supply (Kossak, 1983). The European bison are also flexible grazers as indicated by the composition of their diversified diet. In the Russian part of the Białowieża Forest, the diet on European bison consists of 376 plant species (Koročkina, 1972). According to Borowski \& Kossak (1972), bison consume 137 plant species (grasses were not identified), 
including aboveground parts of herbaceous plants, browse of trees and shrubs, and bark. In the growing season, the diet of European bison is dominated by herbaceous plants accounting for $67 \%$ of the diet, and the remaining $33 \%$ consist of trees and shrubs (Borowski \& Kossak, 1972). In summer, the daily food consumption is $8.4 \mathrm{~kg}$ for calves less than one year old, $19.4-28 \mathrm{~kg}$ for the young $2-3$ years old, and 22.7 and $32.2 \mathrm{~kg}$ fresh weight for cows and bulls 4-5 years old, respectively (Gębczyńska $\&$ Krasinska, 1972). These high food requirements in bison are the main factor determining their movements in the forest complex. As herbaceous plants are the basic component of the bison diet, seasonal changes in the available food supply in the forest floor should play an important regulatory role in the foraging activity of these animals. This is particularly clear cut during the development of the herb layer in spring. Browsing and bark contributes more to the diet in early spring, after the bison leave the sites with artificial food supply. Mainly in this period bison make damages to young deciduous stands because of barking. Owing to phenological differences in the phases of plant growth and development among different forest types in the Białowieża Forest (Falińska 1973), seasonal changes in the habitat preference by bison are observed.

Deciduous forests (fresh and moist) and mixed deciduous forests are habitat types in which bison forage throughout the growing season. The more intense searching of deciduous forests in early spring can be explained by the earliest development of the herb layer in this part of the forest (Falinska, 1973). At that time Anemone nemorosa grow abundantly and form the basic item of the bison diet. The herb layer of deciduous forests contains the largest number of species readily consumed by bison (according to the classification by Borowski \& Kossak. 1972). Among the plant with a long vegetation period, extending from spring to autumn (Falinska, 1973), four species (Aegopodium podagraria, Stachys silvatica, Ranunculus lanuginosus, and Urtica dioica) are preferred by bison. At the flowering peak of the herb layer, in April and May, the number of species readily eaten by bison is the highest in these forest types, and this corresponds to the highest preference of these habitats. The frequency of visits to deciduous forests increases by the third ten-day period of May and throughout June. On the turn of June, in deciduous forest two plants readily eaten by bison flower: Aegopodium podagraria and Stachys silvatica, and on the turn of July, when the number of visits to deciduous and mixed forests increases again, nettles, Urtica dioica, flower there in masses and they are readily grazed by bison. Thus, deciduous forests are visited throughout the grcwing season because they contain plants with both short and long, extending by the late autumn, vegetation period. The increase in the 
i.itensity of searching of deciduous forests in autumn can be explained by the fact that in August and September they comprise some rhizome plants, which regrow in the juvenile form (e.g. Galeobdolon luteum and Oxalis acetosella), and can supplement the diet of bison in that period. The composition of the herb layer of deciduous forests in autumn is similar to that in spring, only the species composition being simplified (Falinska, pers. comm.).

The mixed forest, covering a small proportion of the siudy area, is visited by bison throughout the growing period. Places are known in the Białowieża Forest, where bison come especially to this habitat.

Another habitat frequently visited by bisons is the mixed coniferous forest. In spring, bisons come to this habitat a little later than to the deciduous forest because plant growth begins a little later there (Falinska, 1973). The first phase of flowering of herbaceous plants in MCF coincides with the flowering phase in DF. Bison most prefer this forest type in June and July, thus at the flowering peak of herbaceous plants (Falinska, 1973). In July, Calamagrostis arundinacea which is one of the four most preferred plants in the diet of bison (Borowski \& Kossak, 1972) is flowering there. Most herbaceous plants, which in this habitat flower in early spring, are eaten by bison also later, at the peak of the [lowering in June and July.

The species composition of the herb layer and its phenological phases in the mixed coniferous forest has a transitional character between coniferous and deciduous forests (Falinska, 1973). A high similarity to deciduous forests, particularly in early spring, accounts for an alternate utilization of these two habitats by bison. If in any given year the herb layer of DF is poor, bison move to MCF. In the years with a shortened growing season, no difference occurs in visiting these habitats.

Forest types preference in bison was earlier investigated by Borowski \& Kossak (1972) and also Krasinski (1978), though this was not the main subject of the latter author. In the present study, bison equally used DF and MCF in the period without snow cover but the preference for these forest types changed seasonally. They clearly preferred tree stands more than 10 years old. In open areas (clearcuts, young plantations up to 10 years, and meadows) they were less frequently encountered (20\% of observations). But this was not always the case. At the end of the $1960 \mathrm{~s}$, bison clearly preferred habitats rich in food plants, thus fresh, mixed and moist deciduous forests (Borowski \& Kossak, 1972; Krasiniski, 1978. Also recently, bison less frequently visit open areas than in the 1960 s. This can be related to changes in forest management (no clearcuts) and cessasion of mowing mid-forest meadows, which resulted in abandoning by bison the sites strongly preferred until 1973. 
In earlier studies, mixed groups of bison rarely preferred the southern part of the population range, where groups of bulls were concentrated (Krasinski, 1978). Mixed groups most frequently visited then northern and central parts of the range with a clear predominance of deciduous forests (fresh, moist and mixed). When in the early 1970s, the second winter aggregation was ultimately formed, the population split into two parts in the period without snow cover (Fig. 1), the groups we studied, remained in central and southern parts of the forest, and more frequently than in earlier years stayed in MCF. In these areas the proportion of MCF is highest. It can be suggested that bison adjusted their feeding habits ta the currently existing food supply.

The preference of bison for stands of different age classes turned out to be similar to that shown by red deer in the Bialowieża Forest. The highest densities of red deer have been recorded in pole-size and timber stands, whereas roe deer preferred younger stands (Pucek et al., 1975). Young plantations had a positive effect on the density of Cervidae until their mean proportion reached $9.1-12 \%$ of forest compartment area (Pucek et al., 1975). No relationship was found, however, between the frequency of bison observations and the proportion of plantations in forest compartments.

The highest frequency of bison visits was noted in forest compartments dominated by DF and MCF. The latter was visited by bison at an increasing frequency from mid-May to the end of July. But especially attractive habitats were deciduous forests, rich in plant species grazed by bison. DF in lowland complexes inhabited by free-living herds of bison is an important limiting factor in the areas suitable for bison introduction. In DF of the Bialowieza Forest, food is available to bison throughout the growing season. This forest is utilized by selective cutting (with a cutting area not exceeding $0.08-0.12 \mathrm{ha}$ ), that increases the mosaic of age classes in these stands. The mosaic of habitats and diversity of age classes in them increase the proportion of ecotones in contemporary forests, and according to Dzięciołowski (in litt.) enhance the explosion of ungulate population in forests of Europe.

The fact that herbivores move from one forest type to another during the year, following their increasing food supply, was noted by Falinski \& Falinska (1986). They also emphasize that bison in the Bialowieza Forest are highly dispersed in small groups so that they do not disturb the structure and dynamics of forest ecosystem as a whole. Movements of bison within their range are mostly determined by their foraging activity, and they ensure an optimum utilization of food supply, that is, they do not overgraze forest habitats and allow the regeneration of the herb layer. Bison never use the whole vegetation, they forage in 
the biotopes where herbaceous plants are at the peak of their growth, a ad after several or a dozen or so days they return to the same place. Their returns in the same seasons of successive years to the same fragments of their home ranges can be related to the seasonal phase of their food plants, combined with a good memory and knowledge of the Rabitat by bison.

\subsection{Fluctuations in Food Supply Verwus Habitat Utilization by European Bison}

Several-year observations revealed differences in habitat preference in bison, which can be explained by changes in food supply related to changes in climatic conditions. These changes differentially affect various forest types, including plant phenology and food resources for bison. It should be noted here that bison as consumers of grasses and forbs of the forest floor are more susceptible to changes in natural food supply than other large herbivores. For example, and increase in the frequency of visits to the mixed conifercus forest in April 1980, when the herb layer was poor because of the delayed spring (information of the Bialowieża Geobotanical Station, University of Warsaw), probably can be explained by insufficient food supply in the deciduous forest, in which bison forage first in the early spring. In June of 1978 and 1979 , which markedly differed in climatic conditions, shifts in habitat preference were observed. The withering of the herb layer in MCF in September of 1979 and 1982 as a result of drought accounted for a larger than in cther years decrease in visiting these forest types by bison. In the years cf changed phenology of the herb layer in preferred biotopes in particular seasons, bison compensated for food deficiency by changing the seasonal pattern of habitat utilization and extending searching range.

To sum up, we can state that the strategy of forest utilization by bison is based on interactions of the group size and structure, preference of forest habitats, and rotatory use of the same patches that prevent an cvergrazing. The bison population in the Bialowieża Forest is perfectly adapted to the present habitat conditions in it. Territorial stability of mixed groups in successive years provides evidence that the stability of food resources, access to water sources, and movements within home ranges ensure adequate food supply throughout the growing seasor without need for a further expansion of the population. Bigger migrations of bulls in western part of the forest can be explained as a result of aggression of other bulls rather than searching for food. Social and spatial structure of the population and also the strategy of habitat utilization are such that bison can satisfy their requirements and, at the same time, biocenotic resources are stable. 
Acknowledgements: Many thanks are due to Professor $Z$. Pucek for his cenera! suggestions and critical reading of the first draft of this paper. Professors $\mathrm{K}$. FaIinska and J. B. Faliński offered valuable comments on vegetation phenology, and Dr. J. L. Olszewski made available climatic data from the Białowieza Primeval Forest. Technical assistants $J$. Dackiewicz and M. Szuma took part in all the field work. Without their help this research would not be possible. Spectal thanks are also due to J. Dackiewicz for his graphical work.

\section{REFERENCES}

1. Borowski S. \& Kossak S., 1972: The nataral food preferences of the European bison in seasons free of snow cover. Acta theriol. 17: $151-169$.

2. Bresiński W, 1982: Grouping tendencies in roe deer under agrocenosis conditions. Acta theriol., 27: 427-447.

3. Caboń-Raczyńska K., Krasińska M. \& Krasiński $Z$., 1983; Behaviour and daily activity rhythm of European bison in winter. Acta theriol., 28: 273-299.

4. Falinska K., 1973: Seasonal dynamics of herb layer in forest communities of Bialowieża National Park. Phytocenosis, 2: 1-120.

5. Falinski J. B. \& Falinska K., 1986: Vegetation dynamics in temperate lowland primeval forest. Ecological studies in Bialowieża forest, NE - Poland. Dr W. Junk Publ.: 1--518. The Hague, Boston, London.

6. Gęcczyńska Z. \& Krasińska M., 1972: Food preferences and requirements of European bison. Acta therial., 17: 105-117.

7. Hofmann R. R., 1978: Die Stellung der europäischen Wildwiederkauer im System der $\ddot{A}$ ssungstypen. |In: Hofmann R. R., ed., "Wildbiologische Informationen für den Jäger"]. Jagd + Hege-Verlag: 1-142. St Gallen.

8. McHugh T, 1972: The time of the buffalo. A. A. Knopt: 1-339. New York.

9. Jarman P. J., 1974: The social organization of antelope in relation to their ecology. Behaviour, 48: 215-267.

10. Karcov G. 1903: Belovežskaja Pušča. Artist. Zaved. AF Marksa: 1-414. S-Petersburg.

11. Korockkina L. N., 1972: Travjanistaja rastitelnost' $v$ pitanii zubrov Belovežskoj Pušči. Belovežskaja Pušca, Issledovani ja, 6: 110-124.

12. Kossak S., 1983: Trophic relations of roe deer in a fresh deciduous forest. Acta theriol., 28: 83-127.

13. Krasiński Z., 1967: Free living European bison. Acta theriol., 12: 391-105.

14. Krasinski Z. A., 1978: Dynamics and structure of the European bison population in the Bialowieźa Primeval Forest. Acta theriol., 23: 13-48.

15. Krasinski Z. A., 1983: The first 10 years of fres breeding of bisons in. the Bialowieża Primeval Forest 1952-1961. Parki nar. Rez. przyr., 4: 39-50.

16. Krasiński Z. \& Raczyński J., 1967: The reproduction biology of European bison living in reserves and in freedom. Acta theriol, 12: 407-444.

17. Lott D. F. \& Minta S. C., 1983: Random individual association and social group instability in American bison (Bison bison). Z. Tierpsychol, 61: 153-172.

18. Pucek Z., Bobek B., Eabudzki L., Milkowski L., Morow K. \& Tomek A., 1975: Estimates of density and number of ungulates. Pol. ecol. Stud., I: 121-136.

19. Scibor J., 1959: Beobachtungen über die in Freiheit lebenden Wisente im Urwald von Białowjeża. Acta theriol., 3: 312-314.

20. Shackleton A. M., 1968: Comparative aspects of social organization of American bison. Ph. D. thesis, University of Western Ontario; 1-67. London, Canada.

21. Soper J. D., 1941: History, range and home life of the northern bison. Ecological monogr., 11: 347-412, 
22. Tempany I. R. \& Cooper S., 1976: Bison concentrations and distributions on primary ranges, October 1974 - October 1976. |In: Stelfox J. G., ed., "Wood Buffalo National Park Bison Research 1972-76. 1976 Annual Report"l. Canadian Wildlife Service Parks, Canada: E1--E11, Edmonton.

23. Tulloch D. G., 1978: The water buffalo, Bubalus bubalis, in Australia: grouping and home range. Aust. Wildl. Res., 5: 327-354.

24. Vuren Van D., 1983: Group dynamics and summer home range of bison in southern Utah. J. Mammal., 64: 329-332.

25. Wróblewski K., 1927: Zubr Puszczy Białowieskiej. Monografia. Wyđ. Pol.: 1-232. Poznan.

Received 16 September 1985, Accepted 10 March 1987.

Malgorzata KRASINSKA, Krystyna CABON-RACZYNSKA

i Zbigniew A. KRASINSSKI

\author{
STRATEGIA UZYTKOWANIA SRODOWISKA PRZEZ ZUBRY \\ W PUSZCZY BIAEOWIESKIEJ
}

\title{
Streszczenie
}

W pracy zbadano zmienność struktury liczebnej i socjalnej grup mieszanych żubrów w Puszczy Bialowieskiej oraz areały zajmowane przez te grupy, wybiórczośc biotopowa oraz sposób wykorzystania zasobów pokarmowych siedlisk leśnych. Badaniami objęto grupy mieszane żubrów, posiadające $w$ swym składzie osobniki znakowane lub rozpoznawane po cechach charakterystycznych, pochodzace $z$ jednego ugrupowania zimowego, bytującego w oddziale 422 (Ryc. 1).

Grupy mieszane, obok nie omawianych w niniejszej pracy grup bykow, sa naturalna formą egzystencji żubrów $w$ sezonie bez pokrywy śnieżnej. Liczebność i struktura grup ulega częstym zmianom (Tabela 1, Ryc. 2). Zmiany te sa uwarunkowane rytmem ważnych procesów życiowych (ruja, sezon wycieleñ oraz innymi czynnikami jak nakrywanie sie areałów, częste spotkania grup i wymiana osobników) i dotycza osobrików wszystkich klas wiekowo-plciowych. Najmniej trwale są związki mločzieży, a najbardziej trwalym elementem grupy sa dorosle krowy (Ryc. 5). Grupy liczace do 20 osobników, spotykane sa najczęściej a zatem jest to optymalna wielkość stad w warunkach środowiska leśnego.

Na strukturę przestrzenną grup mieszanych $w$ okresie od kwietria do października wywieraja wplyw zwiazki powstale $w$ dwóch duzych ugrupowaniach zimowych. Grupy powstałe z różnych ugrupowań okupuja oddzielne, względnie stałe arealy (Ryc. 1). Badane przez nas grupy mieszane, pochodzace z jednego zimowego ligrupowania (oddz. 422) od kwietnia do października zajmuja terytorium 6480 ha. Arealy poszczególnych grup sa mniejsze, zachodzą na siebie, srednio wynosza 4700 ha \pm 720.2 . Wielkośc areału grupy ulega zmianom sezonowym, najmniejsza jest $w$ kwietniu, największa $w$ maju (2802 ha, Tabela 3), kiedy to róźni się istotnie od wielkosici areałow w pozostałych miesiącach. Sredni miesięczny areał grupy mieszanej wynosi 2100 ha $\$ 885.7$. W różnych sezonach zmianom ulega również tempo 
penetracji terenu (Tabela 3). Grupa mieszana przebywa średnio na dobę $2034 \mathrm{~m} \pm$ \pm 1415.8 , najdluższo dystanse notuje się $w$ maju (śr. $2438 \mathrm{~m}$ ).

W kolejnych latach $w$ tym samym sezonie zubry penetruja staly fragment puszczy (Ryc. 10), chociaż wielkość arealu grupy bywa różna w zależności od zasobności bazy żerowej. Areały różnych grup nachodzą na siebie (Ryc. 7), dochodzi do częstych spotkań grup i wymiany osobników.

Wędrówki żubrów $w$ okresie bez pokrywy śnieżnej, poza okresem aktywnosici seksualnej byków związane są głównie z zerowaniem. Zubry wykorzystuja bazr. żerowa siedlisk stosując jakby "naprzemienny wypas", przechodząc do sasiednich siedlisk aby powrócić $w$ poprzednie miejsce po kilku do kilkunastu dniach. Sredni czas powrotu grupy $w$ to samo miejsce wynosi 6,6 dnia. Powoduje to uniknięcie nadmiernego zużycia środowiska i umożliwia regenerację roślinności runa (Ryc. 8, 9).

Podczas sezonu wegetacyjnego żubry w sposób zróżnicowany wykorzystują mozaike siedlisk leśnych puszczy (Tabela 4). Najbardziej wykorzystane sa lasy liściaste (Lśw i Lw) oraz bór mieszany świeży (80\% frekwencji spotkań) - Ryc. 13, 14 Wykorzystanie biotopów zmienia się sezonowo. Na wiosnę preferowane są lasy liściaste, w ciągu lata bory mieszane świeże a jesienią ponownie wzrasta udzial lasów liściastych i mieszanych (Ryc. 15, 16). Las mieszany jest wysoce preferowany mimo skąpego udziału tego siedliska na terenie badan. Zubry spotykano najczęściej żerujące na runie lasu w wieku powyżej 20 lat ( $77 \%$ spotkañ), rzadziej na zrębach $i$ uprawach do 10 lat $(23 \%$ ) (Tabela 6, Ryc. 14). Zubry intensywniej penetruja tereny, gdzie preferowany biotop występuje $w$ wysokim udziale (Tabela 5). Nie stwierdzono natomiast zależności między frekwencją spotkań żubrów $w$ danym oddziale a powierzchnia zrębów i upraw (Tabela 7).

Optymalne wykorzystanie zasobów żerowych lasu jest możliwe dzięki znacznej plastyczności pokarmowej żubrów. W latach o zaburzonej fenologii rozwoju runa $w$ preferowanych biotopach, zwierzeta rekompensuja niedobory pokarmowe zmieniając sezonowośc wykorzystania siedlisk i rozszerzając areal penetracji.

Populacja żubrów w Puszczy Bialowieskiej doskonale przystosowala się do jej obecnych warunków środowiskowych. Stalość terytoriów grup mieszanych w kolejnych latach dowodzi, że stabilność zasobów pokarmowych, dostępność żródel wody i wędrówki w obrębie arealu stwarzaja możliwość zaspokojenia potrzeb pokarmowych w ciagu calego sezonu wegetacyjnego, bez potrzeby dalszego rozprzestrzeniania się populacji utrzymującej się na stalym poziomie liczebności. Taki sposób użytkowania środowiska zapewnia populacji wlaściwe wykorzystanie bazy żerowej, zabezpieczając jednocześnie stabilnośé zasobów pokarmowych biocenozy.

Porównano sezonowe zmiany preferencji biotopowej żubrów ze szczytami kwitnienia roślin runa $w$ preferowanych siedliskach $f$ stwierdzono, ze wzrostowi preferencji danego siedliska lasu odpowiada szczyt kwitnienia roślin runa, które sa wówczas szczególnie chętnie jedzone przez żubry. 